\title{
応答変位法を用いた円筒地中構造物の縦断方向 の耐震性評価に関する波動論的考察
}

\author{
保田 尚俊 ${ }^{1} \cdot$ 塚田 和彦 ${ }^{2} \cdot$ 朝倉 $\quad$ 俊弘 $^{3}$ \\ 1正会員 京都大学助教 工学研究科社会基盤工学専攻（ $\mathbf{T}$ 615-8540 京都市西京区京都大学桂 C) \\ E-mail: yasuda.naotoshi.3x@kyoto-u.ac.jp \\ 2 非会員 京都大学准教授 工学研究科社会基盤工学専攻（ $\bar{T}$ 615-8540 京都市西京区京都大学桂 $\mathrm{C}$ ) \\ E-mail: tsukada@kumst.kyoto-u.ac.jp \\ 3 正会員 NPO 法人トンネル工学研究会理事長（广101-0044 東京都千代田区鍛冶町 1 丁目 5-6) \\ E-mail: asakura@tunnel-eng.or.jp
}

\begin{abstract}
無限に広がる地盤内に存在する円筒形線状地中構造物に地震波が入射した際，その構造物に生じる軸直交方 向の変形を応答変位法により評価することに関して, 弾性波動論にもとづき再考した。 その結果, 次のことが明 らかとなった．構造物を円筒シェル，周辺地盤を各方向に独立な軸方向と軸直交方向の 2 つの地盤ばねで表し， 入力する地盤変位を適切に扱った応答変位法は, 構造物に生じる変形を上手く表現でき, 弾性波動論の厳密解 とも良く一致する。一方，従来の構造物を梁とするモデルでは，構造と地盤の境界面における軸方向の力の釣 り合いを無視しているので, 軟質地盤内の円筒地中構造物に対して S 波が浅い角度で入射するような, 軸曲げ 変形によって構造物に大きな軸ひずみが生じる場合では, 構造物に生じる軸ひずみを過大評価することとなる.
\end{abstract}

Key Words : seismic wave, underground structure, seismic deformation method, bending deformation, elastodynamics

\section{1.はじめに}

線状地中構造物の縦断方向の耐震性の評価には，簡 便かつ有効な解析手法として応答変位法が良く用いら れている1),2),3). しかしながら，地盤ばね定数の決め方 や入力として構造物に作用させる地盤の地震時変位の 扱い方など，応答変位法に用いられている種々の仮定 には議論すべき余地が残されている.

筆者らは，既報 4 )において，地震波によって円筒形線 状地中構造物に生じる “軸方向の変形 (軸伸縮変形)” 応答変位法により評価することの妥当性を弾性波動論 の立場から再考した。その結果, 数 $\mathrm{Hz}$ 程度までの一般 的な地震波による線状地中構造物の応答評価において は，地盤ばね定数と構造物に作用させる地盤の地震時 変位を適切に扱った応答変位法は, 構造物に生じる軸 方向の変形を上手く評価でき, 弾性波動論の厳密解と も良い一致を示すこと，また，その際に用いる地盤ば ね定数は，周波数を無視することはできず，特に軸直 交方向の地盤内における見かけの波長を考慮すべきこ となどの知見を得ている.

本論文はこれに続くものであり，地震波によって線状 地中構造物に生じる “軸直交方向の変形 (軸曲げ変形)” を応答変位法により評価することの妥当性について, 弾 性波動論の立場から再考するものである，すなわち，対 象を円筒形の弾性体地中構造物とし，それに対してあ
る周波数の平面地震波が入射したときの波動場の厳密 解 5 ),6) を基礎として, 構造物の軸直交方向の変形を評価 する際に用いられる応答変位法の種々の仮定の妥当性 について議論する.さらに, その結果と前報での議論を あわせて, 円筒地中構造物が地震時にうける縦断方向 の変形 (軸伸縮変形と軸曲げ変形) を評価する応答変位 法とそれを用いた耐震設計の考え方について総括する.

\section{2. 軸直交方向の変形を評価するための応答 変位法}

線状地中構造物の軸直交方向の変形を評価するため の応答変位法の基礎方程式は, 曲げのみを受ける梁と して構造物をモデル化し, 構造物の慣性を無視した次 式で表される1).

$$
E_{(2)} I \frac{\partial^{4}}{\partial z^{4}} u_{b(2)}=K_{B}\left(u_{b(1)}^{e}-u_{b(2)}\right)
$$

ここで, $E_{(2)}, I$ は構造物のヤング率, 断面 2 次モーメ ント, $K_{B}$ は軸直交方向の地盤ばね定数, $u_{b(1)}^{e}, u_{b(2)}$ はそれぞれ地盤, 構造物の軸直交方向変位を表す. 式 (1) から分かるように, 構造物の剛性は断面 2 次モ一メ ントで表現されており, その断面の形状は任意である. 以降では, 地盤, 構造物は弾性体とし, 地盤に関する ものには下付き添字 (1) ，構造物に関するものには 下付き添字 $(2)$ をつけ, 一般的な表現の場合には下付き 
添字をつけないものとする．また，上付き添字の $\mathrm{e}$ は 地中構造物を取り除いて空洞だけとしたときの地盤 (以 降，これを切り欠き地盤と呼ぶ)を表すものとする.

応答変位法を用いる際に入力する地盤変位としては, 切り欠き地盤の空洞壁面での変位を用いることが正し (1),7)が，あらかじめそれを求めておくことは容易でな い. そのため，一般には構造物も空洞もない一様な地 盤 (以降，これを自然地盤と呼ぶ) での変位を用いるこ とが多い.この自然地盤での変位を用いる場合には，基 礎式は補助項をつけた次式とすべきである.

$$
E_{(2)} I \frac{\partial^{4}}{\partial z^{4}} u_{b(2)}=K_{B}\left(u_{b(1)}^{f}-u_{b(2)}\right)+\tau_{b}^{f}
$$

ここで, $u_{b(1)}^{f}$ は自然地盤での軸直交方向変位であり(以 降，上付き添字の $f$ は自然地盤を表す), $\tau_{b}^{f}$ は空洞の部 分にも地盤が存在することの影響を補償する項 (以降, これを切り欠き力と呼ぶ)である.

式 (1)のつり合い式は, 地震による地盤変位によって 線状の地中構造物に曲げが生じるとき，構造物が曲げ 剛性を有しているがために発生する反力 (左辺) と, 構 造物がないとした場合に地盤に生じる変位 $u_{b(1)}^{e}$ を実際 の変位 $u_{b(2)}$ に抑制するために必要な力 (右辺) とが等 しい，ということを表す式である．実際の変位や力は 構造物と地盤との境界において作用しているものであ るが, 式 (1) は 1 次元の式であるので, $u_{b(2)}$ は構造物 全体としてのたわみ，すなわち曲げ最大方向の軸直交 変位であり, $u_{b(1)}^{e}$ も構造物を取り除いた空洞を有する 地盤に生じる一様な軸直交変位を表すものと考える必 要がある. また, $K_{B}$ を地盤ばね定数と定義したが，こ れは構造物と地盤との境界における作用の詳細を無視 した合算的な効果として, 構造物の軸直交方向の変位 に対して作用するものと考える必要がある.

以降では，この応答変位法の妥当性を弾性波動論の 立場から検討するため, 円筒形の構造物が均質な無限 地盤内にあるものと仮定する.

\section{3. 応答変位法と弾性波動論より得られる構 造物の変形モードとの対応}

\section{（1）弾性波動論より得られる 1 次の軸曲げ変形モード}

図-1にあるように，無限に広がる弾性体地盤内に存 在する弾性体の円筒形線状地中構造物に地震波が作用 する問題を考える.ここでは, 地震波が調和振動の平面 波の重ね合わせで表現できることを前提とし，任意の 角周波数 $\omega$ の調和振動平面波が波数べクトル $\boldsymbol{k}^{\mathrm{inc}}$ の方 向に進行し，構造物に対してある角度 $\phi$ で入射する問 題を考える. 入射 $\mathrm{P}$ 波による地盤変位を $\boldsymbol{u}_{p}^{f}, \mathrm{~S}$ 波の場 合を $\boldsymbol{u}_{s}^{f}$ とする. $\boldsymbol{u}_{s}^{f}$ は構造物横断面と平行な面内に変位 成分 $\boldsymbol{u}_{s_{1}}^{f}$ をも波 (以降, これを $\mathrm{S}_{1}$ 波とする) と, 構造

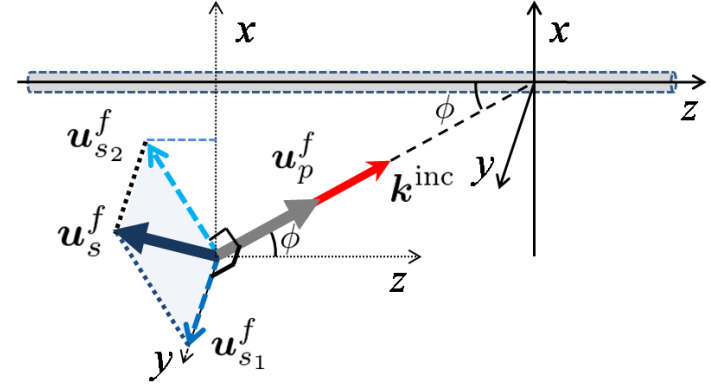

図-1 円筒形線状地中構造物への地震波入射

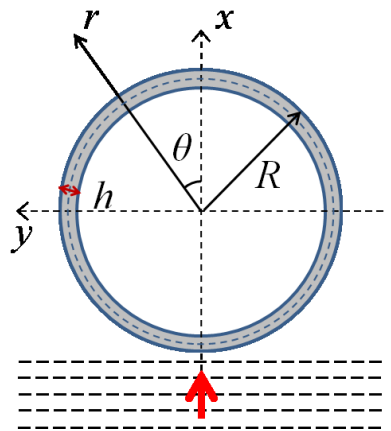

図-2 構造物断面図

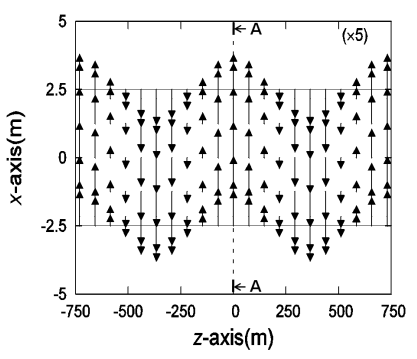

(a) 縦断面

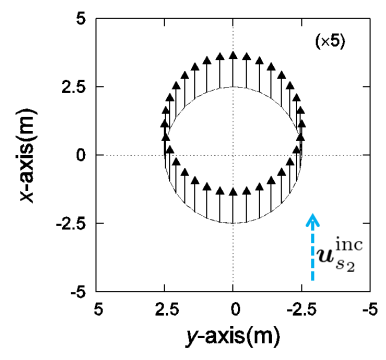

(b) 断面 AA
図-3 円筒形線状地中構造物の軸曲げ変形モード

物縦断面内に変位成分 $\boldsymbol{u}_{s_{2}}^{f}$ を持つ波 (以降, これを $\mathrm{S}_{2}$ 波とする)に分解して考える. 座標系は図-1, 図-2の ように定義し，以降では引張を正とする.

弾性波動論を用いると, 円筒形線状地中構造物の地震 時挙動は円筒座標系の固有関数の和で表現でき5),6), 応 答変位法と弾性波動論より得られる構造物の変形モ一 ドとの対応を考えると，軸直交方向の変形を評価する ために用いられる応答変位法は, 1 次の軸曲げ変形モ一 ドを評価するもの(ここでの 1 次とは, 横断面 $\theta$ 方向の Fourier 級数の次数である) と考えることができる4).

そこで以降では, 式 (1) または式 (2) で表現される応 答変位法が，この 1 次モードの軸曲げ変形を引き起こ す地震荷重に対する構造物の応答を算定するものであ るとの立場から議論する.

参考までに，本論文で対象とする 1 次モードの変形 を弾性波動論で計算した例を図-3に示す．図は，周波 数が $1.00 \mathrm{~Hz}$, 最大変位振幅が $1(\mathrm{~m})$ の $\mathrm{S}_{2}$ 波が $\phi=75$ 度 
で入射する場合に構造物の内壁面で生じる変位の大き さを示したものである (計算に用いた物性等の条件は 4. で述べるものと同じである). 図中右上の数字は変位べ クトルを示す際に変位の各成分に乗じた倍率を表して いる．なお，軸直交方向の変形は $\mathrm{P}$ 波， $\mathrm{S}_{2}$ 波が入射し た場合では $x$ 軸方向に，また $\mathrm{S}_{1}$ 波が入射した場合では $y$ 軸方向に生じる.

\section{(2) 1 次の軸曲げ変形モードに関して地盤と構造物の 境界面で成り立つ関係式}

角周波数 $\omega$ の平面波がある角度をもって円筒地中構 造物に入射している場合について考える。この際，構 造物からの反射波も含めて, 領域全体にある定常的な 波動場が実現しているとし，以降では波動場の多数の モードのうち 1 次モードの変位場だけを対象とする.

1 次の変形モードの場合, 応答変位法を用いる際の入 力として, 切り欠き地盤での変位を用いるよりも, 自 然地盤での変位と切り欠き力を用いた方が考察が容易 となる，そのため, 以降では, 後者の方法で地盤と構 造物の境界面で成り立つ関係式を導出する. なお, こ こでは $\mathrm{S}_{2}$ 波入射の場合を仮定して考察するが， $\mathrm{P}$ 波入 射や $\mathrm{S}_{1}$ 波入射の場合でも，同様の議論を展開できる.

\section{a) 円筒座標系で表された関係式}

構造物と地盤との境界面 $(r=R)$ における 1 次モード の変位の一般的な表現は，次式となる.

$$
\left.\begin{array}{c}
u_{r}^{1}=U_{r}^{1} \cos \theta e^{i(\gamma z-\omega t)} \\
u_{\theta}^{1}=U_{\theta}^{1} \sin \theta e^{i(\gamma z-\omega t)} \\
u_{z}^{1}=-i U_{z}^{1} \cos \theta e^{i(\gamma z-\omega t)}
\end{array}\right\}, r=R
$$

ここで, $U_{r}^{1}, U_{\theta}^{1}, U_{z}^{1}$ は, 構造物と地盤との境界面に おける, 1 次モードの変形の振幅を表す複素数である. 以降， 1 次の変形モードに関する量には上付き添字の 1 を付ける， $\gamma, L_{z}$ は地盤に生じる軸方向の見かけの波 数, 波長である. $U_{z}^{1}$ に虚数単位の $(-i)$ を掛けているの は, 地震波によって自然地盤に生じる 1 次の変形モ一 ドにおいては, $u_{r(1)}^{1, f}, u_{\theta(1)}^{1, f}$ と $u_{z(1)}^{1, f}$ には必ず 90 度の位 相差があることをふまえたものである (後の式 (21) お よび (22)を参照のこと). これにより，後に導出する地 盤や構造の剛性を表す係数行列が対称行列となる.

構造物と地盤との境界面 $(r=R)$ で生じる 1 次モード の表面力の一般的な表現は, 変位の場合と同様に, 次 式となる.

$$
\left.\begin{array}{rl}
f_{r}^{1} & =F_{r}^{1} \cos \theta e^{i(\gamma z-\omega t)} \\
f_{\theta}^{1}= & F_{\theta}^{1} \sin \theta e^{i(\gamma z-\omega t)} \\
f_{z}^{1}=-i F_{z}^{1} \cos \theta e^{i(\gamma z-\omega t)}
\end{array}\right\}, r=R
$$

土木学会論文集A1 構造 地震工学), Vol. 74, No. 1, 44 57, 2018.

ここで, $F_{r}^{1}, F_{\theta}^{1}, F_{z}^{1}$ は, 構造物と地盤との境界面にお ける, 1 次モードの表面力の振幅を表す複素数である. なお, 表面力 $f^{1}$ の正 (引張) の方向は図 $-\mathbf{1}$, 図 $-\mathbf{2}$ の座 標系の定義と一致するものとする.

境界面での表面力と変位のそれぞれの振幅を表す係 数の間で成り立つ関係式は, 次式で表現できる.

$$
\left(\begin{array}{c}
F_{r}^{1} \\
F_{\theta}^{1} \\
F_{z}^{1}
\end{array}\right)=\left(\begin{array}{lll}
K_{r r}^{1} & K_{r \theta}^{1} & K_{r z}^{1} \\
K_{r \theta}^{1} & K_{\theta \theta}^{1} & K_{\theta z}^{1} \\
K_{r z}^{1} & K_{\theta z}^{1} & K_{z z}^{1}
\end{array}\right)\left(\begin{array}{c}
U_{r}^{1} \\
U_{\theta}^{1} \\
U_{z}^{1}
\end{array}\right)
$$

この式の係数行列は 1 次の変形モードに対する剛性を 表すものである.

自然地盤 $(r=R)$ での 1 次の切り欠き力 $\tau_{r}^{1, f}, \tau_{\theta}^{1, f}$, $\tau_{z}^{1, f}$ は，同様に次式で表現できる.

$$
\begin{aligned}
& \tau_{r}^{1, f}=\sigma_{r r(1)}^{1, f}=\Sigma_{r r(1)}^{1, f} \cos \theta e^{i(\gamma z-\omega t)} \\
& \left.\tau_{\theta}^{1, f}=\sigma_{r \theta(1)}^{1, f}=\Sigma_{r \theta(1)}^{1, f} \sin \theta e^{i(\gamma z-\omega t)}\right\}, r=R \\
& \left.\tau_{z}^{1, f}=\sigma_{r z(1)}^{1, f}=-i \Sigma_{r z(1)}^{1, f} \cos \theta e^{i(\gamma z-\omega t)}\right)
\end{aligned}
$$

$\Sigma_{r r(1)}^{1, f}, \quad \Sigma_{r \theta(1)}^{1, f}, \quad \Sigma_{r z(1)}^{1, f}$ は振幅を表す複素数である.

地盤と構造物の境界面での力の釣り合い，および境 界面は分離しないとする変位の適合条件を考慮すると, 次式が成立する。

$$
\begin{aligned}
& \left(\begin{array}{lll}
K_{r r(2)}^{1} & K_{r \theta(2)}^{1} & K_{r z(2)}^{1} \\
K_{r \theta(2)}^{1} & K_{\theta \theta(2)}^{1} & K_{\theta z(2)}^{1} \\
K_{r z(2)}^{1} & K_{\theta z(2)}^{1} & K_{z z(2)}^{1}
\end{array}\right)\left(\begin{array}{c}
U_{r(2)}^{1} \\
U_{\theta(2)}^{1} \\
U_{z(2)}^{1}
\end{array}\right)= \\
& \left(\begin{array}{lll}
K_{r r(1)}^{1} & K_{r \theta(1)}^{1} & K_{r z(1)}^{1} \\
K_{r \theta(1)}^{1} & K_{\theta \theta(1)}^{1} & K_{\theta z(1)}^{1} \\
K_{r z(1)}^{1} & K_{\theta z(1)}^{1} & K_{z z(1)}^{1}
\end{array}\right)\left(\begin{array}{c}
U_{r(1)}^{1, f}-U_{r(2)}^{1} \\
U_{\theta(1)}^{1, f}-U_{\theta(2)}^{1} \\
U_{z(1)}^{1, f}-U_{z(2)}^{1}
\end{array}\right)+\left(\begin{array}{c}
\Sigma_{r r(1)}^{1, f} \\
\Sigma_{r \theta(1)}^{1, f} \\
\Sigma_{r z(1)}^{1, f}
\end{array}\right)
\end{aligned}
$$

この式は 1 次の軸曲げ変形を扱う応答変位法の基礎式 を円筒座標系において厳密に扱ったものである. $U_{r(1)}^{1, f}$, $U_{\theta(1)}^{1, f}, U_{z(1)}^{1, f}$ は代入すべき自然地盤での境界面 $(r=R)$ における 1 次モードの変位振幅. $U_{r(2)}^{1}, U_{\theta(2)}^{1}, U_{z(2)}^{1}$ は 求めようとしている円筒地中構造物が存在するときの 地盤と構造物の境界面 $(r=R)$ における変位振幅である. また, 上式の両辺にある係数行列は，1次の変形モード に対する構造物および地盤それぞれの剛性であり，後 に導出するものである.

\section{b）直交座標系で表された関係式}

以降では, 1 次モードの変形を扱う応答変位法の厳密 式 (8)に基づいて，これまでに良く用いられている軸直 交方向の変形を扱う応答変位法の式 (2) の妥当性につ いて議論する。そこで，まず円筒座標系で表された式 (8) を直交座標系に変換することを考える.

円筒座標系で表された変位の一般解である式 (3) を 
直交座標系へ変換すると,

$$
\left(\begin{array}{c}
u_{x}^{1} \\
u_{y}^{1} \\
i u_{z}^{1}
\end{array}\right)=\left(\begin{array}{ccc}
\cos ^{2} \theta & -\sin ^{2} \theta & 0 \\
\frac{1}{2} \sin 2 \theta & \frac{1}{2} \sin 2 \theta & 0 \\
0 & 0 & \cos \theta
\end{array}\right)\left(\begin{array}{c}
U_{r}^{1} \\
U_{\theta}^{1} \\
U_{z}^{1}
\end{array}\right) e^{i(\gamma z-\omega t)}
$$

となり, これをさらに変形すると, 次式となる.

$$
\left(\begin{array}{c}
u_{x}^{1} \\
u_{y}^{1} \\
i u_{z}^{1}
\end{array}\right)=\left(\begin{array}{ccc}
1 & \cos 2 \theta & 0 \\
0 & \sin 2 \theta & 0 \\
0 & 0 & \cos \theta
\end{array}\right)\left(\begin{array}{c}
\frac{U_{r}^{1}-U_{\theta}^{1}}{2} \\
\frac{U_{r}^{1}+U_{\theta}^{1}}{2} \\
U_{z}^{1}
\end{array}\right) e^{i(\gamma z-\omega t)}
$$

この式から，仮に地震波によって励起される 1 次モ一 ドの変形に以下の条件,

$$
\text { (1) } U_{r}^{1}+U_{\theta}^{1} \approx 0
$$

が成り立つならば, 式 (10) の $2 \theta$ の項を無視することが できるので, 軸直交方向の変形は振幅 $U_{x}^{1}=\left(U_{r}^{1}-U_{\theta}^{1}\right) / 2$ の $x$ 軸方向への一様な変形とみなすことができ, 式 $(10)$ は次式のように簡略化できる.

$$
\left(\begin{array}{c}
u_{x}^{1} \\
i u_{z}^{1}
\end{array}\right)=\left(\begin{array}{c}
U_{x}^{1} \\
U_{z}^{1} \cos \theta
\end{array}\right) e^{i(\gamma z-\omega t)}
$$

変位と同様に, 円筒座標系で表された表面力の一般 解式 (5) も直交座標系へ変換すると, 次式が成立する.

$$
\left(\begin{array}{c}
f_{x}^{1} \\
f_{y}^{1} \\
i f_{z}^{1}
\end{array}\right)=\left(\begin{array}{ccc}
1 & \cos 2 \theta & 0 \\
0 & \sin 2 \theta & 0 \\
0 & 0 & \cos \theta
\end{array}\right)\left(\begin{array}{c}
\frac{F_{r}^{1}-F_{\theta}^{1}}{2} \\
\frac{F_{r}^{1}+F_{\theta}^{1}}{2} \\
F_{z}^{1}
\end{array}\right) e^{i(\gamma z-\omega t)}
$$

表面力においても, 軸直交方向の表面力の振幅は, $x$ 軸 方向への一様な成分 $\left(F_{r}^{1}-F_{\theta}^{1}\right) / 2$ と $\left(F_{r}^{1}+F_{\theta}^{1}\right) / 2$ の $2 \theta$ で分布する成分に分けて考えることができる.

円筒座標系で表された境界面での表面力と変位の振 幅間の関係式 $(6)$ は次式のように変換できる.

$\left(\frac{\frac{F_{r}^{1}-F_{\theta}^{1}}{F_{r}^{2}+F_{\theta}^{1}}}{2}\right)=$

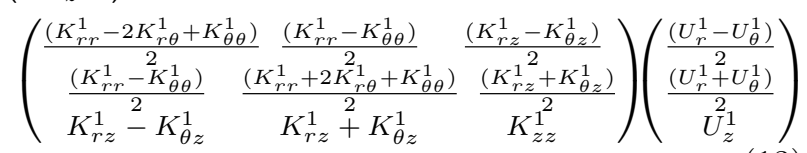

今，条件(1)が成立するとし，断面内の表面力について は $x$ 軸方向の一様な成分のみ問題とすることにすれば, 境界面において扱うべき力は

$$
\left(\begin{array}{c}
f_{x}^{1} \\
i f_{z}^{1}
\end{array}\right)=\left(\begin{array}{c}
F_{x}^{1} \\
F_{z}^{1} \cos \theta
\end{array}\right) e^{i(\gamma z-\omega t)}
$$

と表すことができる.ここで $F_{x}^{1}=\left(F_{r}^{1}-F_{\theta}^{1}\right) / 2$ であ る.この場合には, 境界面において問題とすべき表面 力および変位の振幅間の関係式は以下となる.

$$
\left.\begin{array}{l}
\left(\begin{array}{l}
F_{x}^{1} \\
F_{z}^{1}
\end{array}\right)=\left(\begin{array}{ll}
K_{x x}^{1} & K_{x z}^{1} \\
K_{z x}^{1} & K_{z z}^{1}
\end{array}\right)\left(\begin{array}{l}
U_{x}^{1} \\
U_{z}^{1}
\end{array}\right) \\
K_{x x}^{1}=\frac{1}{2}\left(K_{r r}^{1}-2 K_{r \theta}^{1}+K_{\theta \theta}^{1}\right) \\
K_{z x}^{1}=2 K_{x z}^{1}=K_{r z}^{1}-K_{\theta z}^{1}
\end{array}\right\}
$$

土木学会論文集A1 構造 地震工学), Vol. 74, No. 1, 44 57, 2018.

同様に, 円筒座標系で表された自然地盤での 1 次の 切り欠き力を直交座標系に変換すると, 次式となる。

$$
\left(\begin{array}{c}
\tau_{x}^{1, f} \\
\tau_{y}^{1, f} \\
i \tau_{z}^{1, f}
\end{array}\right)=\left(\begin{array}{ccc}
1 & \cos 2 \theta & 0 \\
0 & \sin 2 \theta & 0 \\
0 & 0 & \cos \theta
\end{array}\right)\left(\begin{array}{c}
\frac{\Sigma_{r r(1)}^{1, f}-\Sigma_{r \theta(1)}^{1, f}}{2} \\
\frac{\Sigma_{r r(1)}^{1, f}+\Sigma_{r \theta(1)}^{1, f}}{2} \\
\Sigma_{r z(1)}^{1, f}
\end{array}\right) e^{i(\gamma z-\omega t)}
$$

この 1 次の切り欠き力について, (1)と同様に次の条件,

$$
\text { (2) } \Sigma_{r r(1)}^{1, f}+\Sigma_{r \theta(1)}^{1, f} \approx 0
$$

が成り立つならば，式 (17) の $2 \theta$ の項を無視すること ができる. その場合, 軸直交方向の切り久き力は振幅 $\Sigma_{x x}^{1, f}=\left(\Sigma_{r r(1)}^{1, f}-\Sigma_{r \theta(1)}^{1, f}\right) / 2$ で $x$ 軸方向へ一様に作用す るものとみなすことができ, 応答変位法で扱うべき切り 欠き力は次式となる.

$$
\left(\begin{array}{c}
\tau_{x}^{1, f} \\
i \tau_{z}^{1, f}
\end{array}\right)=\left(\begin{array}{c}
\Sigma_{x x}^{1, f} \\
\Sigma_{r z}^{1, f} \cos \theta
\end{array}\right) e^{i(\gamma z-\omega t)}
$$

以上の考察を踏まえると，条件(1)おび条件(2が満 足される場合では, 1 次モードの変形を扱う円筒座標系 における応答変位法の基礎式 (8) は, 直交座標系におい ては，次式のように表現できることになる.

$$
\begin{aligned}
& \left(\begin{array}{l}
K_{x x(2)}^{1} K_{x z(2)}^{1} \\
K_{z x(2)}^{1} K_{z z(2)}^{1}
\end{array}\right)\left(\begin{array}{l}
U_{x(2)}^{1} \\
U_{z(2)}^{1}
\end{array}\right)= \\
& \left(\begin{array}{l}
K_{x x(1)}^{1} K_{x z(1)}^{1} \\
K_{z x(1)}^{1} K_{z z(1)}^{1}
\end{array}\right)\left(\begin{array}{l}
U_{x(1)}^{1, f}-U_{x(2)}^{1} \\
U_{z(1)}^{1, f}-U_{z(2)}^{1}
\end{array}\right)+\left(\begin{array}{c}
\Sigma_{x x}^{1, f} \\
\Sigma_{r z}^{1, f}
\end{array}\right)
\end{aligned}
$$

なお，境界面において㗢く力のうち $2 \theta$ で分布する成分 の振幅 $\left(F_{r}^{1}+F_{\theta}^{1}\right) / 2$ については, 式 $(19)$ で求まった変 位から，式 (13)をもとに副次的に計算できる.

式 (19) の応答変位法と式 (2) の梁モデルによる従来 の応答変位法が同等であるためには, 地盤の剛性と構 造物の剛性の両方において, 以下の条件

$$
\text { (3) } K_{r z}^{1}-K_{\theta z}^{1}=0
$$

が成立し, 式 (19) が $x$ 方向と $z$ 方向とで独立な式に表 現できなければならない.

\section{4. 直交座標系で表された 1 次の軸曲げ変形 を扱う応答変位法の妥当性の検討}

以降では，条件(1および(2)について吟味し，式 (19) の直交座標系で表した軸曲げ変形を扱う応答変位法の 基礎式の妥当性について考察する. 加えて, 式 (2) で表 される従来の応答変位法が有効となるための条件(3)に ついても考察する.

\section{（1）地盤と構造物の境界面の位置で生じる変位}

\section{a) 入射 $\mathbf{S}_{2}$ 波によって自然地盤に生じる変位}

まず, 自然地盤における变位振幅 $\left(U_{r(1)}^{1, f}, U_{\theta(1)}^{1, f}\right)$ が条 件(1)を満足するかを考える. 体積力を無視すると, 弾 
性波動論に用いられる基礎方程式は次式で表される5).

$$
\left(\lambda_{(1)}+\mu_{(1)}\right) \nabla \nabla \cdot \boldsymbol{u}_{(1)}+\mu \nabla^{2} \boldsymbol{u}_{(1)}=\rho_{(1)} \ddot{\boldsymbol{u}}_{(1)}
$$

$\rho_{(1)}$ および $\lambda_{(1)}, \mu_{(1)}$ は地盤の密度，ラメの定数であ

る. 式 $(20)$ を満足する変位の一般解は, 次式となる.

$$
\left.\begin{array}{l}
u_{r(1)}=\frac{\partial \varphi}{\partial r}+\frac{1}{r} \frac{\partial \psi}{\partial \theta}+\frac{1}{k_{s(1)}} \frac{\partial^{2} \chi}{\partial r \partial z} \\
u_{\theta(1)}=\frac{1}{r} \frac{\partial \varphi}{\partial \theta}-\frac{\partial \psi}{\partial r}+\frac{1}{k_{s(1)} r} \frac{\partial^{2} \chi}{\partial \theta \partial z} \\
u_{z(1)}=\frac{\partial \varphi}{\partial z}-\frac{1}{k_{s(1)}}\left\{\frac{1}{r} \frac{\partial}{\partial r}\left(r \frac{\partial \chi}{\partial r}\right)+\frac{1}{r^{2}} \frac{\partial^{2} \chi}{\partial \theta^{2}}\right\}
\end{array}\right\}
$$

$\varphi$ は $\mathrm{P}$ 波, $\psi$ と $\chi$ は S 波を表すポテンシャル関数であ り，波動方程式を満たすものである。

入射平面 $\mathrm{S}_{2}$ 波 (変位振幅 $\left|\boldsymbol{u}_{s(1)}^{f}\right|=U_{s(1)}^{f}$ とする)によつ て生じる自然地盤変位の中で, 1 次の軸曲げ変形モード に寄与する成分を導出するためのポテンシャル関数は 次式のようにおける6).

$$
\left.\begin{array}{c}
\varphi=\psi=0 \\
\chi=-\frac{2 i U_{s(1)}^{f}}{\beta_{(1)}} J_{1}\left(\beta_{(1)} r\right) \cos \theta e^{i(\gamma z-\omega t)}
\end{array}\right\}
$$

ここで, $k_{s(1)}, L_{s(1)}$ は地盤内に生じる $\mathrm{S}$ 波の波数，波 長, $\beta_{(1)}, L_{s t(1)}$ は地盤内に生じる $\mathrm{S}$ 波の軸直交方向の 見かけの波数，波長である。また， $J_{1}$ は 1 次の第 1 種 ベッセル関数である。

式 $(20) \sim(23)$ より，入射 $\mathrm{S}_{2}$ 波によって自然地盤 $(r=R)$ に生じる 1 次モードの変位振幅は, 次式となる.

$$
\left.\begin{array}{l}
U_{r(1)}^{1, f}=2 U_{s(1)}^{f} \frac{\gamma}{k_{s(1)}}\left\{J_{0}\left(\beta_{(1)} R\right)-\frac{J_{1}\left(\beta_{(1)} R\right)}{\beta_{(1)} R}\right\} \\
U_{\theta(1)}^{1, f}=-2 U_{s(1)}^{f} \frac{\gamma}{k_{s(1)}} \frac{J_{1}\left(\beta_{(1)} R\right)}{\beta_{(1)} R} \\
U_{z(1)}^{1, f}=2 U_{s(1)}^{f} \frac{\beta_{(1)}}{k_{s(1)}} J_{1}\left(\beta_{(1)} R\right)
\end{array}\right\}
$$

ここで， $J_{0}$ は 0 次の第 1 種ベッセル関数である.

一般的な地震波 (周波数 $10 \mathrm{~Hz}$ 程度以下の波) の場合 では, 構造物の直径 $2 R$ に対して $\mathrm{S}$ 波の波長 $L_{s(1)}$ が十 分に長いので $\left(\beta_{(1)} R\right.$ は十分小さな值とみなせるので $)$, 式 (24) は $\beta_{(1)} R$ の 2 次の項までの近似で次式のように 表すことができる。

$$
\left.\begin{array}{l}
U_{r(1)}^{1, f} \approx U_{s(1)}^{f} \frac{\gamma}{k_{s(1)}}\left\{1-\frac{3}{8}\left(\beta_{(1)} R\right)^{2}\right\} \\
U_{\theta(1)}^{1, f} \approx-U_{s(1)}^{f} \frac{\gamma}{k_{s(1)}}\left\{1-\frac{1}{8}\left(\beta_{(1)} R\right)^{2}\right\} \\
U_{z(1)}^{1, f} \approx U_{s(1)}^{f} \frac{\beta_{(1)}^{2} R}{k_{s(1)}}
\end{array}\right\}
$$

表-1 物性值

\begin{tabular}{lccc}
\hline & $\begin{array}{c}\text { ヤング率 } \\
(\mathrm{GPa})\end{array}$ & ポアソン比 & $\begin{array}{c}\text { 密度 } \\
\left(\mathrm{kg} / \mathrm{m}^{3}\right)\end{array}$ \\
\hline 地盤 & 0.200 & 0.400 & 2000 \\
構造物 & 20.0 & 0.200 & 2000 \\
\hline \multicolumn{3}{c}{} \\
\multicolumn{3}{c}{ 表-2 } & 解析条件 \\
\hline 構造物内側の半径 $(\mathrm{m})$ & 構造物の厚さ $(\mathrm{m})$ \\
\hline \multicolumn{2}{c}{2.5} & 0.25 \\
\hline
\end{tabular}

上式で, $U_{r(1)}^{1, f}$ と $U_{\theta(1)}^{1, f}$ の絶対值の差異は $\beta_{(1)} R$ の 2 次の項のみに表れており，これを無視できるとすると $U_{r(1)}^{1, f} \approx-U_{\theta(1)}^{1, f}$ と見なせることから, 一般的な入射 $\mathrm{S}_{2}$ 波 によって自然地盤に生じる 1 次モードの変位振幅は, 条 件(1)を満たすと判断できる。このとき，自然地盤に生 じる 1 次モードの変位振幅の $x$ 方向成分は次式で,

$$
U_{x(1)}^{1, f} \approx U_{s(1)}^{f} \frac{\gamma}{k_{s(1)}}=U_{s(1)}^{f} \cos \phi
$$

また, $U_{z(1)}^{1, f}$ は $U_{x(1)}^{1, f}$ を用いて次式で表せる.

$$
U_{z(1)}^{1, f} \approx \frac{\beta_{(1)}^{2} R}{\gamma} U_{x(1)}^{1, f}
$$

\section{b）地盤と構造物の相互作用の結果として生じる変位}

次に地盤と構造物の相互作用の結果としてその境界 面に生じる 1 次モード変位振幅 $\left(U_{r(2)}^{1}, U_{\theta(2)}^{1}\right)$ が条件(1) を満たすかについて, 弾性波動論を用いて具体的に計 算することで考察する.

本研究で用いる物性值等の条件は, 軟質地盤に覆わ れたトンネルを想定し，表-1，表-2 に示すものを用い る. なお，ここで設定した地盤の入力值では $\mathrm{P}$ 波， $\mathrm{S}$ 波 の速度は約 $463 \mathrm{~m} / \mathrm{s}$ ，約 $189 \mathrm{~m} / \mathrm{s}$ となる.

図-4 は振幅 $1(\mathrm{~m})$ の $\mathrm{S}_{2}$ 波 $\left(U_{s(1)}^{f}=1\right)$ が入射する場合 の, 地盤と構造物の境界面 $(r=R=2.75 \mathrm{~m})$ における 1 次 の軸曲げ変形による変位振幅を弾性波動論で計算し, 比 較したものである．横軸には，軸方向の見かけの波長に 加えてその波長となる入射角 $\phi$ の值も示している. 図よ り, $1.00 \mathrm{~Hz}, 5.00 \mathrm{~Hz}$ どちらの場合でも, $U_{r(2)}^{1}+U_{\theta(2)}^{1}$ は $U_{r(2)}^{1}-U_{\theta(2)}^{1}$ よりも十分に小さいことが分かる.よって, 地盤と構造物の相互作用の結果として生じる 1 次モ一 ドの変位に関しても，条件(1)を満たすと判断できる.

\section{（2）空洞でなく地盤が存在することを補償する力}

入射 $\mathrm{S}_{2}$ 波 $\left(\left|\boldsymbol{u}_{s(1)}^{f}\right|=U_{s(1)}^{f}\right.$ とする $)$ の場合, 式 (17) の 自然地盤 $(r=R)$ での 1 次の切り欠き力を表す項は, 弾 性波動論を用いて計算すると, $\beta_{(1)} R$ の 2 次の項までの 


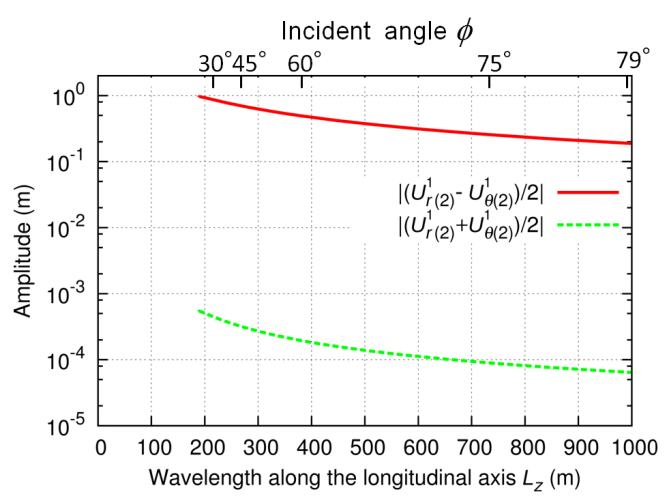

(a) 周波数 $1.00 \mathrm{~Hz}$ の場合

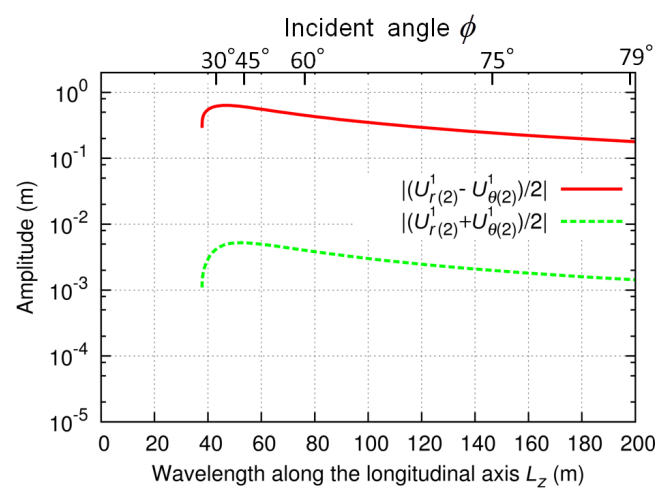

(b) 周波数 $5.00 \mathrm{~Hz}$ の場合

図-4 地盤と構造物の境界面での半径方向変位と周方向変位 の振幅の比較 $\left(\mathrm{S}_{2}\right.$ 波入射 $)$

近似で次式のようになる.

$$
\left.\begin{array}{rl}
\frac{\Sigma_{r r(1)}^{1, f}-\Sigma_{r \theta(1)}^{1, f}}{2} & \approx-U_{x(1)}^{1, f} \frac{\mu_{(1)}}{R}\left(\beta_{(1)} R\right)^{2} \\
\frac{\Sigma_{r r(1)}^{1, f}+\Sigma_{r \theta(1)}^{1, f}}{2} & \approx-U_{x(1)}^{1, f} \frac{\mu_{(1)}}{2 R}\left(\beta_{(1)} R\right)^{2} \\
\Sigma_{r z(1)}^{1, f} & \approx U_{x(1)}^{1, f} \frac{\mu_{(1)}}{R} \frac{\left(\beta_{(1)} R\right)^{2}-(\gamma R)^{2}}{\gamma R}
\end{array}\right\}
$$

式 $(25)$ の場合と同様に, $\left(\beta_{(1)} R\right)^{2} \approx 0$ と見なせるとす ると, $\left(\Sigma_{r r(1)}^{1, f}-\Sigma_{r \theta(1)}^{1, f}\right) / 2$ や $\left(\Sigma_{r r(1)}^{1, f}+\Sigma_{r \theta(1)}^{1, f}\right) / 2$ はほぼ ゼロとなるので，条件(2)および，次式が成り立つ.

$$
\Sigma_{x x}^{1, f} \approx 0
$$

$\Sigma_{r z(1)}^{1, f}$ は, 式 (23), 式 (26), 式 (28) を用いると次式 のように書き直すことができる。

$$
\begin{aligned}
\Sigma_{r z(1)}^{1, f} & \approx U_{x(1)}^{1, f} \mu_{(1)} \frac{\beta_{(1)}^{2}-\gamma^{2}}{\gamma} \\
& \approx-U_{s(1)}^{f} \mu_{(1)} \frac{2 \pi}{L_{s(1)}} \cos 2 \phi
\end{aligned}
$$

以上の 4.(1) および 4.(2) の考察から, 地盤中の線 状構造物に一般的な地震波が作用する問題においては, 条件(1), (2)がともに成立し, その際の軸直交変位を評 価するための基礎式として, 式 (19) が妥当なものであ ると判断できる。

\section{（3）地盤の剛性}

弾性波動論を用いて式 (8) および式 (19) の右辺にあ る地盤の剛性を表す係数行列を導出する. 円筒空洞壁 面から半径方向の無限遠に向かって 1 次の軸曲げ変形 モードに寄与する波が生じている問題では，ポテンシャ ル関数 $\varphi, \psi, \chi$ の一般解は次式のようにおける ${ }^{5)}$.

$$
\left.\begin{array}{l}
\varphi=A_{1} H_{1}^{(1)}\left(\alpha_{(1)} r\right) \cos \theta e^{i(\gamma z-\omega t)} \\
\psi=B_{1} H_{1}^{(1)}\left(\beta_{(1)} r\right) \sin \theta e^{i(\gamma z-\omega t)} \\
\chi=C_{1} H_{1}^{(1)}\left(\beta_{(1)} r\right) \cos \theta e^{i(\gamma z-\omega t)}
\end{array}\right\}
$$

$$
\alpha_{(1)}=\sqrt{k_{p(1)}^{2}-\gamma^{2}}=\sqrt{\left(\frac{2 \pi}{L_{p(1)}}\right)^{2}-\left(\frac{2 \pi}{L_{z}}\right)^{2}}
$$

$A_{1}$ および $B_{1}, C_{1}$ は $\mathrm{P}$ 波および $\mathrm{S}$ 波のポテンシャル 振幅, $k_{p(1)}, L_{p(1)}$ は地盤内での $\mathrm{P}$ 波の波数, 波長であ り， $\alpha_{(1)}$ は地盤内での $\mathrm{P}$ 波の軸直交方向の見かけの波 数である. $H_{1}^{(1)}(x)$ は 1 次の第 1 種のハンケル関数で ある. 式 $(33)$ の定義より， $L_{p(1)}>L_{z}$ の場合に $\alpha$ は 純虚数となるが, $H_{1}^{(1)}(x)$ の $x$ が純虚数となる場合は $H_{1}^{(1)}\left(i x^{\prime}\right)=-2 / \pi K_{1}\left(x^{\prime}\right)$ となり, 第 2 種の変形ベッセ ル関数で表現できる。ここで, $H_{1}^{(1)}(x)$ は複素関数であ り，実部，虚部ともに $x$ に比例して振動しつつも振幅 が徐々に減少していく. 一方, $K_{1}(x)$ は実数関数であ り, $x$ に比例して単調に減少する.

式 (21), 式 (32) より，構造物壁面からの反射波 (散 乱波) による変位場の一般解を導出でき，さらに変位一 ひずみの関係式，等方均質体のひずみ一応力の関係式を 用いて整理することで, 応力 (表面力) の一般解を導出 できる。

地盤の剛性は切り欠き地盤の円筒空洞壁面に単位振幅 の正弦波状変位を生じさせるために必要な表面力と定義 できる. 空洞壁面 $(r=R)$ での変位, 表面力の一般解は式 (3) や式 (5) のように表すことができ, 変位や表面力の 振幅を表す係数 $U_{r(1)}^{1}, U_{\theta(1)}^{1}, U_{z(1)}^{1}$ や $F_{r(1)}^{1}, F_{\theta(1)}^{1}, F_{z(1)}^{1}$ は，係数 $A_{1}, B_{1}, C_{1}$ を未定乗数として含む式として表 される.それらから係数 $A_{1}, B_{1}, C_{1}$ を消去することで, $U_{r(1)}^{1}, U_{\theta(1)}^{1}, U_{z(1)}^{1}$ と $F_{r(1)}^{1}, F_{\theta(1)}^{1}, F_{z(1)}^{1}$ の関係式, すな わち式 (6) で表される地盤の剛性を表す係数行列が導 出できる.なお，これらの剛性の具体的な式に関して は付録 I を参照のこと.

以降では，地盤の剛性を具体的な值を用いて計算し， 条件(3)が成立するか否かを検討する. 図-5 は 2 つの周 波数について軸方向の見かけの波長を変化させながら 地盤の剛性を計算し, 比較したものである. 縦軸 $K^{*}$ は各成分の絶対值を $\mu_{(1)} / R$ で除すことで無次元化して いる. 図より，周波数が低く，軸方向の見かけの波長 が長いほど, $K_{r r(1)}^{1}-2 K_{r \theta(1)}^{1}+K_{\theta \theta(1)}^{1}\left(=2 K_{x x(1)}^{1}\right)$ や $K_{z z(1)}^{1}$ に比べ, $K_{r z(1)}^{1}-K_{\theta z(1)}^{1}\left(=2 K_{x z(1)}^{1}=K_{z x(1)}^{1}\right)$ が相対的に小さくなることが分かる. したがって, 周 


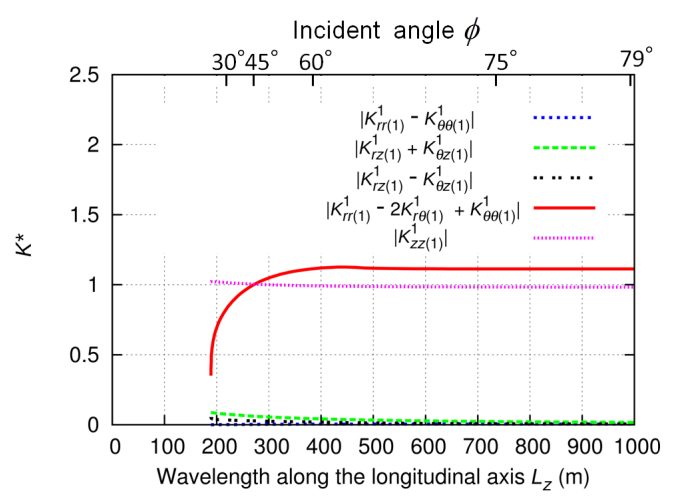

(a) 周波数 $1.00 \mathrm{~Hz}$ の場合

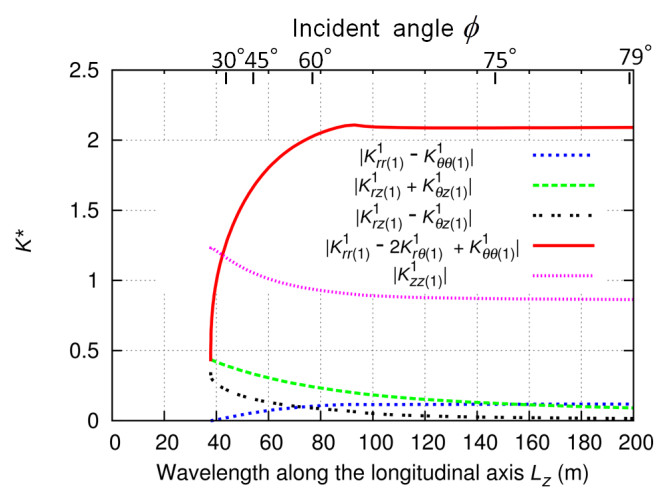

(b) 周波数 $5.00 \mathrm{~Hz}$ の場合

図-5 地盤の剛性の大きさの比較

波数が低く, 軸方向の見かけの波長が長いほど条件(3) は妥当となり, 地盤の剛性は各方向に独立な 2 つの地 盤ばね定数で表現できるようになる。

軸直交方向の地盤の剛性 $K_{x x(1)}^{1}$ に相当する $\left(K_{r r(1)}^{1}-\right.$ $\left.2 K_{r \theta(1)}^{1}+K_{\theta \theta(1)}^{1}\right) / 2$ は, 周波数, 入射角 (軸方向の見か けの波長) とともに大きくなる。一方，軸方向の地盤ば ね定数 $K_{z z(1)}^{1}$ は周波数が高く, 入射角が小さい場合を 除くと，ほぼ一定值となる。

各方向に独立な 2 つ地盤ばね定数 $K_{x x(1)}^{1}$ と $K_{z z(1)}^{1}$ は，具体的には次式で与えられる.

$$
\left.\begin{array}{rl}
K_{x x(1)}^{1}= & \frac{\mu_{(1)}}{2 R} \frac{\left(\beta_{(1)} R\right)^{2}\left(\kappa_{\beta}-4+\frac{\beta_{(1)}^{2}}{k_{s(1)}^{2}} \kappa_{\alpha}+\frac{\gamma^{2}}{k_{s(1)}^{2}} \kappa_{\beta}\right)}{\left(\kappa_{\beta}-1\right)\left(\frac{\beta_{(1)}^{2}}{k_{s(1)}^{2}} \kappa_{\alpha}+\frac{\gamma^{2}}{k_{s(1)}^{2}} \kappa_{\beta}\right)-\kappa_{\beta}} \\
K_{z z(1)}^{1}= & \frac{\mu_{(1)}}{R} \frac{\kappa_{\beta}\left(1-\kappa_{\alpha}\right)\left(\kappa_{\beta}-2\right)+\frac{\beta_{(1)}^{2}}{k_{s(1)}^{2}}\left(\kappa_{\beta}-\kappa_{\alpha}\right)}{\left(\kappa_{\beta}-1\right)\left(\frac{\beta_{(1)}^{2}}{k_{s(1)}^{2}} \kappa_{\alpha}+\frac{\gamma^{2}}{k_{s(1)}^{2}} \kappa_{\beta}\right)-\kappa_{\beta}} \\
\kappa_{\alpha}= & \frac{\alpha_{(1)} R H_{0}^{(1)}\left(\alpha_{(1)} R\right)}{H_{1}^{(1)}\left(\alpha_{(1)} R\right)} \\
\kappa_{\beta}= & \frac{\beta_{(1)} R H_{0}^{(1)}\left(\beta_{(1)} R\right)}{H_{1}^{(1)}\left(\beta_{(1)} R\right)}
\end{array}\right\}
$$

ここで, $H_{0}^{(1)}$ は 0 次の第 1 種のハンケル関数である.
土木学会論文集A1 構造 地震工学), Vol. 74, No. 1, 44 57, 2018.

式 (19) の地盤の剛性 $K_{x x(1)}^{1}$ と式 (2) の軸直交方向の 地盤ばね定数 $K_{B}$ との対応を考えると, $K_{x x(1)}^{1}$ は境界 面上の単位面積あたりで定義された剛性であるのに対 して， $K_{B}$ は境界面全体に対して定義されたものであ る.このため, 両者の対応は次式で表すことができる.

$$
K_{B}=2 \pi R K_{x x(1)}^{1}
$$

\section{（4）構造物の剛性}

構造物の剛性を導出するにあたつては，厚さ $h$ が波 長に比べて十分に小さいと見なせる限り，構造内での 波動場の詳細を考慮する必要性はない，すなわち構造 物の慣性は無視できる. 以降では, 円筒形構造物を中 心半径 $R$, 厚さ $h$ の円筒シェル8) と考え, それに正弦 波状の変位を生じさせる際に必要な表面力を求めるこ とで構造物の剛性を導出する.

半径 $R$ の円筒シェルとみなせる構造物に生じている 1 次の軸曲げ変形に寄与する変位 $u_{r(2)}^{1}, u_{\theta(2)}^{1}, u_{z(2)}^{1}$ お よび表面力 $f_{r(2)}^{1}, f_{\theta(2)}^{1}, f_{z(2)}^{1}$ の一般解が, 式 (3) や式 (5)のように表すことができるとする.このとき, 変位 や表面力の一般解を円筒シェルの微分方程式8)に代入 し, 変位と表面力の関係式として整理することで, 構 造物の剛性は次式のように導かれる.

$$
\begin{aligned}
& K_{r r(2)}^{1}=\frac{D}{R^{2}}+\frac{K}{R^{4}}\left\{2(\gamma R)^{2}+(\gamma R)^{4}\right\} \\
& K_{r \theta(2)}^{1}=\frac{D}{R^{2}}+\frac{K}{R^{4}} \frac{3-\nu_{(2)}}{2}(\gamma R)^{2} \\
& K_{r z(2)}^{1}=\gamma R\left[\frac{D}{R^{2}} \nu_{(2)}+\frac{K}{R^{4}}\left\{-\frac{1-\nu_{(2)}}{2}+(\gamma R)^{2}\right\}\right] \\
& K_{\theta \theta(2)}^{1}=\frac{D}{R^{2}}\left\{1+\frac{1-\nu_{(2)}}{2}(\gamma R)^{2}\right\} \\
& K_{\theta z(2)}^{1}=\gamma R\left[\frac{D\left(1-\nu_{(2)}\right)}{R^{4}}(\gamma R)^{2}\right. \\
& K_{z z(2)}^{1}=\frac{D}{R^{2}}\left\{\frac{1-\nu_{(2)}}{2}\right]
\end{aligned}
$$

$$
\left.\begin{array}{l}
D=\frac{E_{(2)} h}{1-\nu_{(2)}^{2}} \\
K=\frac{E_{(2)} h^{3}}{12\left(1-\nu_{(2)}^{2}\right)}
\end{array}\right\}
$$

$E_{(2)}, \nu_{(2)}$ は構造物のヤング率, ポアソン比, $D, K$ は軸剛性，曲げ剛性を表す係数である。なお，一般的 な条件では, $K / R^{4}$ は $D / R^{2}$ に比べて十分に小さく, $\gamma R\left(=2 \pi R / L_{z}\right)$ は 1 に比べて十分小さい.

以降では, 構造物の剛性を具体的な值を用いて計算し, 条件(3)が成立するか否かを検討する. 図-6 は 2 つの周波 数について軸方向の見かけの波の波長を変化させながら, 構造物の剛性を計算し，比較したものである．縦軸 $K^{* *}$ 


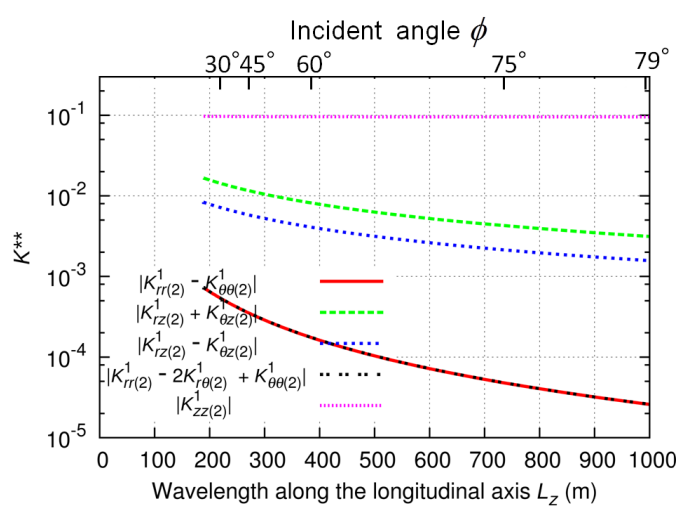

(a) 周波数 $1.00 \mathrm{~Hz}$ の場合

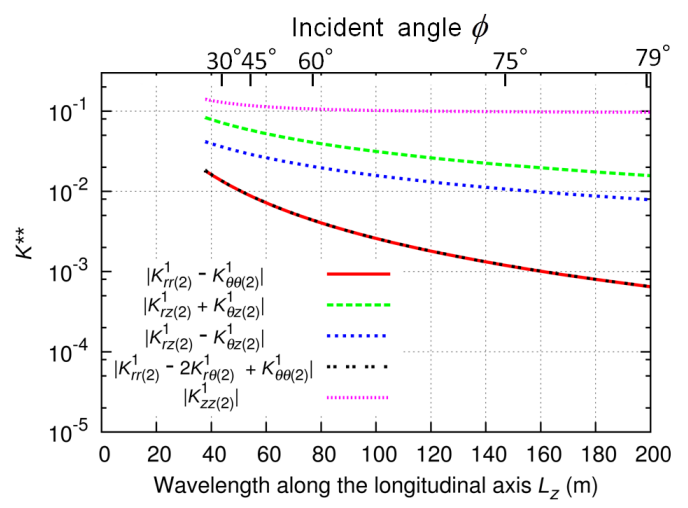

(b) 周波数 $5.00 \mathrm{~Hz}$ の場合

図-6 構造物の剛性の大きさの比較

は各成分の絶対值を $\mu_{(2)} / R$ で除すことで無次元化して いる. 図より，式 (19) の構造物の剛性において $K_{z z(2)}^{1}$ が最も大きく, $K_{r r(2)}^{1}-2 K_{r \theta(2)}^{1}+K_{\theta \theta(2)}^{1}\left(=2 K_{x x(2)}^{1}\right)$ が小さいことが分かる. 非対角項の $K_{r z(2)}^{1}-K_{\theta z(2)}^{1}(=$ $\left.2 K_{x z(2)}^{1}=K_{z x(2)}^{1}\right)$ はそれらの中間の值であってこれを 無視することはできない. よって, 構造物の剛性にお いて条件(3)成立しないと考えなければならない，た とえ地盤の剛性において条件(3)が成立していたとして も, 式 (19) は $x$ 方向と $z$ 方向で互いに独立な式には分 離できず, 従来の応答変位法の式 $(2)$ には無理があると 判断できる。

なお，式(13)によって副次的に計算できる断面内の表 面力 $f_{x}^{1}, f_{y}^{1}$ のうちの $2 \theta$ で分布する成分は，それを支配 する係数 $K_{r r(2)}^{1}-K_{\theta \theta(2)}^{1}$ と $K_{r z(2)}^{1}+K_{\theta z(2)}^{1}$ のうち後者が それほど小さくないことから, その振幅 $\left(F_{r(2)}^{1}+F_{\theta(2)}^{1}\right) / 2$ がある程度の大きさを有すると予想される。このこと は, 弾性波動論における 1 次モードの変形によって構 造物内に若干の周方向ひずみが誘起されていることを 示唆している.

\section{（5）構造物を円筒シェルとした場合の応答変位法}

これまでの検討をまとめれば，まず，軸直交方向の変 形を評価するための応答変位法においては，扱うべき
変位と切り欠き力について条件(1)，(2)が成立すること から，その基礎式として式 (19) は十分妥当であるとい える.さらに，その式において，剛性を表す係数行列の うち，地盤の剛性については条件(3)が成立し，その非 対角項をゼロとみなすことができるが，構造物の剛性 では条件(3)は成立せず，その非対角項を無視すること はできない. 結果として, 式 (27), 式(29), 式 (30)を 用いて式 (19) を整理すると， $\mathrm{S}_{2}$ 波が入射する場合の地 盤と構造物の境界面で成立する関係式は，次式となる。

$$
\begin{aligned}
& \left(\begin{array}{cc}
K_{x x(2)}^{1}+K_{x x(1)}^{1} & K_{x z(2)}^{1} \\
K_{z x(2)}^{1} & K_{z z(2)}^{1}+K_{z z(1)}^{1}
\end{array}\right)\left(\begin{array}{c}
U_{x(2)}^{1} \\
U_{z(2)}^{1}
\end{array}\right)= \\
& \left(\begin{array}{c}
K_{x x(1)}^{1} \\
\frac{\beta_{(1)}^{2} R}{\gamma} K_{z z(1)}^{1}-\frac{\gamma^{2}-\beta_{(1)}^{2}}{\gamma} \mu_{(1)}
\end{array}\right) U_{x(1)}^{1, f}
\end{aligned}
$$

式 (38) は構造物を円筒シェルと仮定した場合の，1 次 の軸曲げ変形を評価するための応答変位法の基礎式で あり，地盤および構造物の剛性を与えれば，自然地盤 での 1 次の変形に寄与する軸直交方向変位 $U_{x(1)}^{1, f}$ から構 造物の変形 $U_{x(2)}^{1}$ および $U_{z(2)}^{1}$ を算出できる式となる.

式 (1), 式 (2) と式 (38) の比較より, 式 (1), 式 (2) は軸直交方向の力の釣り合いのみを考えた式であるが, 式 (38) は軸方向 (境界面でのせん断力) と軸直交方向の 力の釣り合いを考えた式であることが分かる．また，切 り欠き力は, 式 (2) では, 軸直交方向の力の釣り合い式 に含まれているが，式 (38) では，軸方向の力の釣り合 い式に含まれていることが分かる.

なお， $\mathrm{P}$ 波が入射するの場合の応答変位法の基礎式 は，式 (38) の右辺を次式に代えたものとなる.

$$
\left(\begin{array}{c}
K_{x x(1)}^{1} \\
-\gamma R K_{z z(1)}^{1}-2 \gamma \mu_{(1)}
\end{array}\right) U_{x(1)}^{1, f}
$$

また， $\mathrm{S}_{1}$ 波が入射する場合は，式 (38) の左辺にある添 字の $x$ を便宜的に $y$ に置き換え (地盤および構造物の剛 性は $\mathrm{S}_{2}$ 波が入射する場合と同じ.ただし, 円筒座標系 での剛性 $K_{r \theta}^{1}, K_{\theta z}^{1}$ の符号は反対となる), 右辺を次式に 代えたものとなる.

$$
\left(\begin{array}{c}
K_{y y(1)}^{1} \\
-\gamma \mu_{(1)}
\end{array}\right) U_{y(1)}^{1, f}
$$

なお, 式 (38), 式 (39), 式 (40)の $\mu_{(1)}$ を含む項は切り 欠き力を表すものである.

\section{5. 応答変位法の妥当性についての検討}

ここでは $\mathrm{S}_{2}$ 波が入射する場合を例として, 応答変位 法より得られる解と弾性波動論で得られる厳密解とを 比較することで，応答変位法で評価したときの近似の 程度について検討する，以降，下付き添字 $\left(e_{1}\right)$ は弾性 波動論の 1 次の軸曲げ変形モードから得られるもの, 下 


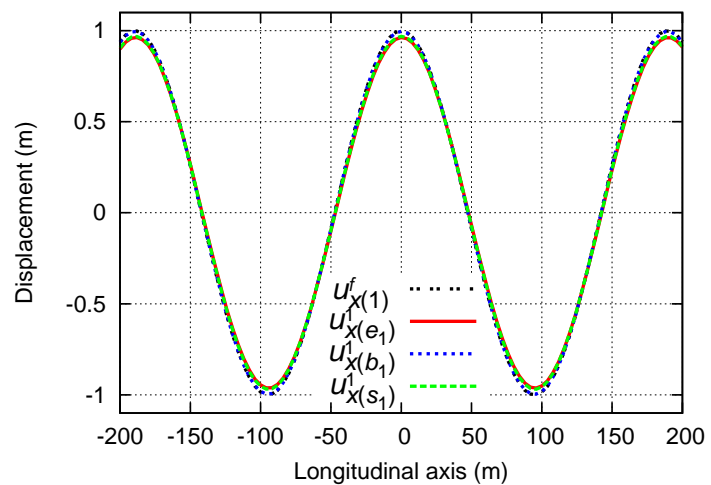

(a) 周波数 $1.00 \mathrm{~Hz}$ の場合 (入射角 $\phi=4^{\circ}$ )

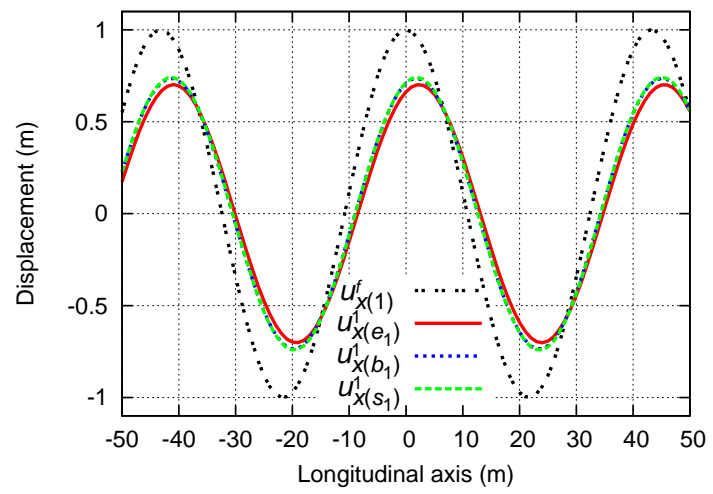

(b) 周波数 $5.00 \mathrm{~Hz}$ の場合 (入射角 $\phi=29^{\circ}$ )

図-7 構造物に生じる軸直交方向変位の比較 $\left(S_{2}\right.$ 波入射 $)$

付き添字 $\left(b_{1}\right)$ は式 $(2)$ の構造物を梁と仮定した応答変 位法から得られるもの $\left(\tau_{b}^{f}=0\right.$ と仮定し, $K_{B}$ として は式 (35) を採用する), 下付き添字 $\left(s_{1}\right)$ は式 (38) の構 造物を円筒シェルと仮定した応答変位法から得られる ものとする. 以降では, 構造物の応答は中心半径の位 置におけるものとし，その応答の位置 $\theta$ は 1 次モード の振幅が最大となる位置，すなわち $\mathrm{S}_{2}$ 波が入射する場 合では $\theta=0^{\circ}$ とする. なお, 構造物の厚さ $h$ は中心半 径 $R$ に比べて小さいため，梁や円筒シェルで仮定する 場合では，地盤と構造物の境界面と構造物の中心半径 は等しいもの $(r=R=2.63 \mathrm{~m})$ とする.

\section{（1）構造物に生じる軸直交方向変位の比較}

図-7 は $\mathrm{S}_{2}$ 波が入射することで自然地盤に生じる軸 直交方向変位の振幅 $U_{x(1)}^{f}\left(=U_{s(1)}^{f} \cos \phi\right)$ を $1(\mathrm{~m})$ とし た場合に構造物に生じる軸直交方向変位 $u_{x(2)}^{1}$ を，弾性 波動論と応答変位法で計算し比較したものである. 解析 に用いた入射角の值は構造物に生じる軸ひずみ $\left(\varepsilon_{z z\left(e_{1}\right)}^{1}\right)$ が最大となる条件のものである．弾性波動論により得 られる $u_{x\left(e_{1}\right)}^{1}$ と構造物を梁とした場合の応答変位法に より得られる $u_{x\left(b_{1}\right)}^{1}$ の振幅の差異は $1.00 \mathrm{~Hz}$ で約 $4 \%$, $5.00 \mathrm{~Hz}$ で $1 \%$ 未満と小さい. また, $u_{x\left(e_{1}\right)}^{1}$ と構造物を円 筒シェルとした場合の応答変位法により得られる $u_{x\left(s_{1}\right)}^{1}$

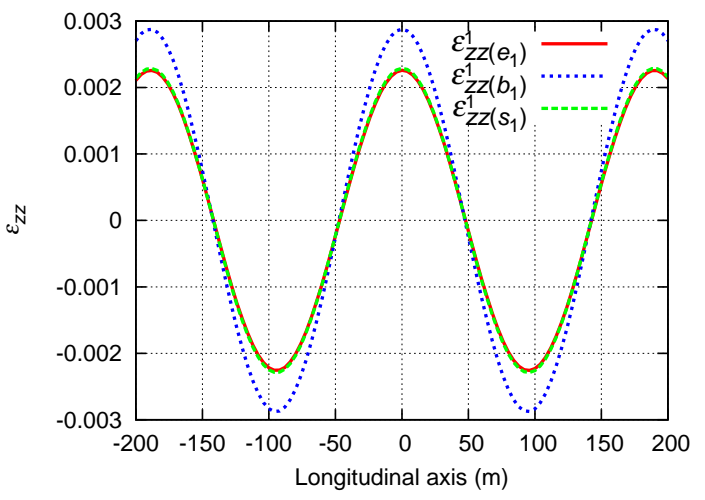

(a) 周波数 $1.00 \mathrm{~Hz}$ の場合 (入射角 $\phi=4^{\circ}$ )

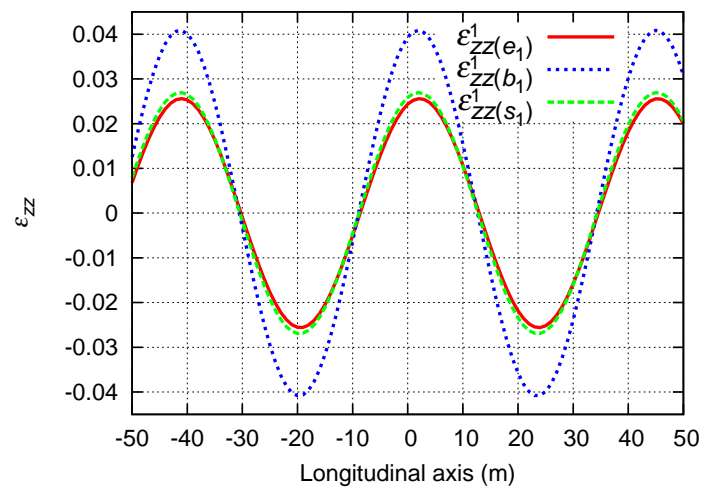

(b) 周波数 $5.00 \mathrm{~Hz}$ の場合 (入射角 $\phi=29^{\circ}$ )

図-8 構造物に生じる軸ひずみの比較 $\left(\mathrm{S}_{2}\right.$ 波入射 $)$

の差異も $1.00 \mathrm{~Hz}$ で $1 \%$ 未満, $5.00 \mathrm{~Hz}$ で約 $6 \%$ と小さい. したがって, いずれの応答変位法を用いても, 構造物 に生じる軸直交方向変位は上手く計算できるといえる.

\section{（2）構造物に生じる軸ひずみの比較}

図-8 は弾性波動論および応答変位法を用いて，図一 7 の軸直交方向変位分布となる時刻の構造物の軸ひずみ を計算し，比較したものである．軸ひずみ $\varepsilon_{z z\left(e_{1}\right)}$ およ び $\varepsilon_{z z\left(s_{1}\right)}$ は次式で計算している.

$$
\varepsilon_{z z\left(e_{1}\right)}=\varepsilon_{z z\left(s_{1}\right)}=\frac{\partial u_{z(2)}}{\partial z}
$$

また，軸ひずみ $\varepsilon_{z z\left(b_{1}\right)}$ は梁理論にもとづき次式で計算 している.

$$
\varepsilon_{z z\left(b_{1}\right)}=-R \frac{\partial^{2} u_{b(2)}}{\partial z^{2}}
$$

$\varepsilon_{z z\left(e_{1}\right)}$ と $\varepsilon_{z z\left(s_{1}\right)}$ を比較すると, 2 つの最大振幅の差異 は $1.00 \mathrm{~Hz}$ で約 $1 \% ， 5.00 \mathrm{~Hz}$ で約 $5 \%$ となり，両者は良 い一致が見られる。一方, $\varepsilon_{z z\left(e_{1}\right)}$ と $\varepsilon_{z z\left(b_{1}\right)}$ を比較する と, $\varepsilon_{z z\left(b_{1}\right)}$ の方が $\varepsilon_{z z\left(e_{1}\right)}$ よりも大きく, 2 つの最大振 幅の差異は $1.00 \mathrm{~Hz}$ で約 $30 \% ， 5.00 \mathrm{~Hz}$ で約 $60 \%$ となり， その差異はかなり大きい。この主な理由は，構造物を 梁とするモデルでは構造と地盤の境界面における軸方 向の力の釣り合いを無視しており, 構造物の曲げ変形 に伴い生じる軸方向の変形が地盤に拘束される影響を 


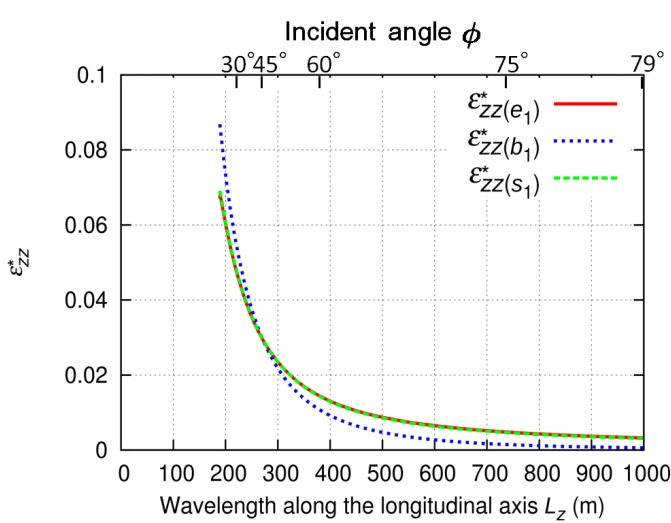

(a) 周波数 $1.00 \mathrm{~Hz}$ の場合

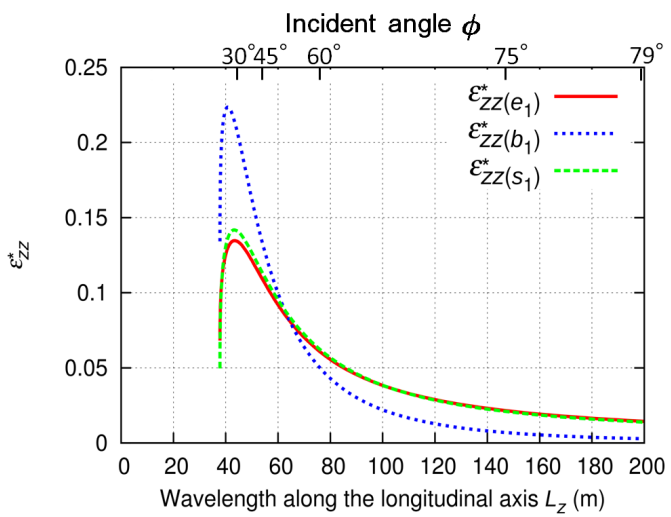

(b) 周波数 $5.00 \mathrm{~Hz}$ の場合

図-9 軸曲げ変形により構造物に生じる軸ひずみの最大振幅 の比較 $\left(\mathrm{S}_{2}\right.$ 波入射 $)$

考虑できないためである。したがって, 線状地中構造 物の軸曲げ変形を考える場合，構造を梁と仮定した従 来の応答変位法では，軸ひずみを上手く評価できない．

図-9 は軸方向の見かけの波長を変化させながら軸曲 げ変形により構造物に生じる軸ひずみの最大振幅を計 算し，比較したものである．縦軸の $\varepsilon_{z z}^{*}$ は自然地盤での せん断ひずみが 1 となる $\mathrm{S}_{2}$ 波が入射した際に構造物に 生じる軸ひずみの最大值である. $\varepsilon_{z z\left(e_{1}\right)}^{*}$ と $\varepsilon_{z z\left(s_{1}\right)}^{*}$ を比 較すると, 良い一致がみられる.一方, $\varepsilon_{z z\left(e_{1}\right)}^{*}$ と $\varepsilon_{z z\left(b_{1}\right)}^{*}$ を比較すると, 入射角 $\phi$ が小さいと $\varepsilon_{z z\left(b_{1}\right)}^{*}$ の方が大き くなり, $\phi$ が大きいと $\varepsilon_{z z\left(b_{1}\right)}^{*}$ の方が小さくなる傾向を 示す。この主な理由は，構造物を梁とした場合では，軸 方向の切り欠き力の影響を上手く表現できていないた めである.

図-10 は構造物に生じる軸曲げ変形による軸ひずみの 最大振幅と周波数の関係を示したものである. 自然地盤 でのせん断ひずみが 1 となる $\mathrm{S}_{2}$ 波が入射する場合につい て，すべての入射角での最大振幅となる軸ひずみとその ときの入射角を示している. 横軸には, 周波数に加えて 構造物の直径と地盤内の $\mathrm{S}$ 波の波長の相対比 $2 R / L_{s(1)}$ も示している. 図より, $\varepsilon_{z z\left(s_{1}\right)}^{*}$ は $\varepsilon_{z z\left(e_{1}\right)}^{*}$ と $2 R / L_{s(1)}$ が小さい場合では良い一致を示すが， $2 R / L_{s(1)}$ が大き

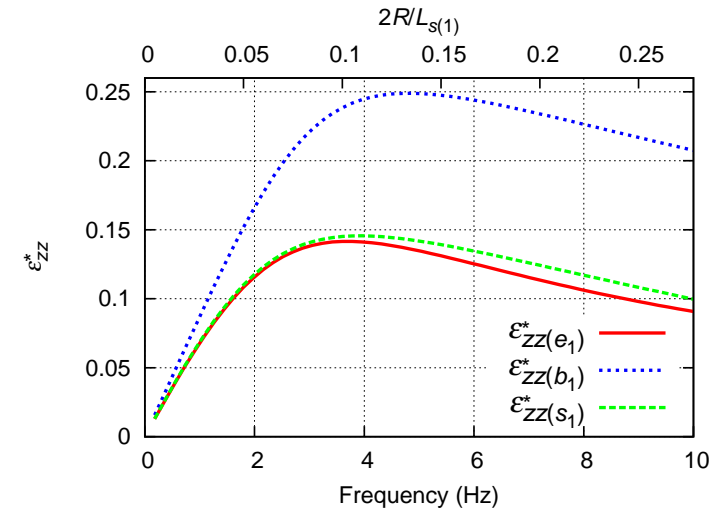

(a) 軸ひずみの最大振幅

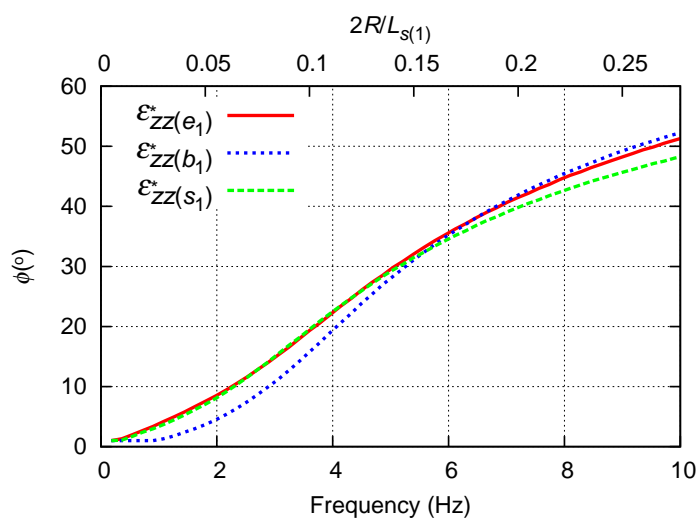

(b) 軸ひずみの振幅が最大となる入射角

図-10 構造物に生じる軸ひずみの最大振幅と周波数の関係 $\left(\mathrm{S}_{2}\right.$ 波入射の場合 $)$

くなるにつれて差異が生じ, 両者の差異は $2 R / L_{s(1)}$ が 0.1 で $1 \%$ 未満, 0.2 で約 $9 \%$ となる。一方, $\varepsilon_{z z\left(b_{1}\right)}^{*}$ は $2 R / L_{s(1)}$ の值に関わらず差異が大きく, $2 R / L_{s(1)}$ が 0.1 で約 70\%，0.2 で約 $90 \%$ となり，構造物を梁と仮定 すると軸ひずみを過大評価する傾向がある.

図に示されているように軸ひずみはある周波数にお いて極大值をもつ単峰性の曲線となっているが，この ことは次のように解釈できる．基本的には周波数が高 くなるにつれ，構造物縦断方向に生じる曲げ変形の曲 率が大きくなり, 構造物に生じる軸ひずみが増大する. その一方で, 構造物の曲げ変形の曲率が増加すると, 式 (36) からわかるように構造物の剛性が高くなり, 変形 が生じにくくなる. それらの結果として, 軸ひずみの最 大振幅はある周波数 (ここでは $4 \mathrm{~Hz}$ 程度) まで増加し， それよりも高くなると減少する。

\section{6. 応答変位法を用いた耐震計算例}

前報4および本報で導出した軸方向および軸直交方向 の変形を評価するための応答変位法を用いた耐震計算 例を示すと共に，その考え方について総括する。一般 的な地震波 ( $\mathrm{S}$ 波) の入射を想定した場合， $\mathrm{S}_{1}$ 波よりも 
構造物縦断方向に変位成分を持つ $\mathrm{S}_{2}$ 波の方が構造物に 大きな軸ひずみが生じるため，ここでも $\mathrm{S}_{2}$ 波が入射す る問題を取り扱う。なお，計算に用いる物性值等の条 件は表 -1 ，表-2 に示したものと同じとする.

\section{(1) 入力する地震変位}

振幅 $U_{s(1)}^{f}$ の $\mathrm{S}_{2}$ 波が角度 $\phi$ で構造物に入射する場合, 応答変位法において入力とすべき自然地盤に生じる軸 方向および軸直交方向の変位は, 次式で表すことがで きる。

$$
\left.\begin{array}{rl}
u_{x(1)}^{f} & =U_{x(1)}^{f} e^{i\left(\beta_{(1)} x+\gamma z-\omega t\right)} \\
& =U_{s(1)}^{f} \cos \phi e^{i\left(\beta_{(1)} x+\gamma z-\omega t\right)} \\
u_{z(1)}^{f} & =U_{z(1)}^{f} e^{i\left(\beta_{(1)} x+\gamma z-\omega t\right)} \\
& =-U_{s(1)}^{f} \sin \phi e^{i\left(\beta_{(1)} x+\gamma z-\omega t\right)}
\end{array}\right\}
$$

ここで，上式の $\beta_{(1)}, \gamma$ は式 (23) で定義されるもので ある. なお, この際, 自然地盤に生じるせん断ひずみ の最大振幅は $U_{s(1)}^{f}\left(2 \pi / L_{s(1)}\right)$ となる.

\section{（2）構造物に生じる応答変位の評価}

\section{a）自然地盤に生じる軸方向の変位に対する応答}

前報4)で得られた結果を要約すれば，軸方向の地震変 位 $u_{z(1)}^{f}$ によって構造物に生じる軸方向変位 $u_{z(2)}^{0}$ を以 下のようにおくと,

$$
u_{z(2)}^{0}=U_{z(2)}^{0} e^{i(\gamma z-\omega t)}
$$

その応答振幅 $U_{z(2)}^{0}$ を求めるための基礎方程式は以下の ように表すことができる.

$$
\left.\begin{array}{l}
2 \pi R K_{z z(2)}^{0} U_{z(2)}^{0}=K_{A}\left(S_{a} U_{z(1)}^{f}-U_{z(2)}^{0}\right) \\
K_{z z(2)}^{0}=D \gamma^{2} \\
K_{A}=2 \pi R \frac{\mu_{(1)} \alpha_{(1)} k_{s(1)}^{2}}{\gamma^{2} h_{01}+\alpha_{(1)} \beta_{(1)} h_{10}} h_{11} \\
h_{i j}=H_{i}^{(1)}\left(\alpha_{(1)} R\right) H_{j}^{(1)}\left(\beta_{(1)} R\right) \\
S_{a}=J_{0}\left(\beta_{(1)} R\right)-J_{1}\left(\beta_{(1)} R\right) \frac{H_{0}^{(1)}\left(\beta_{(1)} R\right)}{H_{1}^{(1)}\left(\beta_{(1)} R\right)}
\end{array}\right\}
$$

$A$ は構造物の断面積, $K_{z z(2)}^{0}$ は 0 次の軸伸縮変形モー ドにおける構造の剛性， $K_{A}$ は 0 次モードにおける軸方 向の地盤ばね定数, $S_{a}$ は自然地盤変位 $U_{z(1)}^{f}$ を切り欠 き地盤変位 $U_{z(1)}^{0, e}$ に変換するための補正係数である.

構造物の軸方向変位の応答振幅 $U_{z(2)}^{0}$ は式 $(45)$ の $U_{z(1)}^{f}$ に $z$ 方向の地震振幅 $-U_{s(1)}^{f} \sin \phi$ を代入した結果 として求められる.

b）自然地盤に生じる軸直交方向の変位に対する応答 軸直交方向の地震変位 $u_{x(1)}^{f}$ に対する構造物の応答変 位の振幅 $\left(U_{x(2)}^{1}, U_{z(2)}^{1}\right)$ は, 以下の式で与えられる（式
（38）を再掲）.

$$
\begin{array}{r}
\left(\begin{array}{cc}
K_{x x(2)}^{1}+K_{x x(1)}^{1} & K_{x z(2)}^{1} \\
K_{z x(2)}^{1} & K_{z z(2)}^{1}+K_{z z(1)}^{1}
\end{array}\right)\left(\begin{array}{c}
U_{x(2)}^{1} \\
U_{z(2)}^{1}
\end{array}\right)= \\
\left(\begin{array}{c}
K_{x x(1)}^{1}{ }^{2}{ }^{2} R \\
\frac{\beta_{(1)}^{2} R}{\gamma} K_{z z(1)}^{1}-\frac{\gamma^{2}-\beta_{(1)}}{\gamma} \mu_{(1)}
\end{array}\right) U_{x(1)}^{1, f}
\end{array}
$$

ここで，地盤の剛性 $K_{x x(1)}^{1}, K_{z z(1)}^{1}$ は式 (34) で示した とおりであり, 構造物の剛性は, 式 (16) と式 (36) から 次式で与えられる.

$$
\left.\begin{array}{rl}
K_{x x(2)}^{1}=\frac{D}{R^{2}} & \frac{1-\nu_{(2)}}{4}(\gamma R)^{2} \\
+ & \frac{K}{R^{4}}\left\{\frac{1-\nu_{(2)}}{4}(\gamma R)^{2}+\frac{(\gamma R)^{4}}{2}\right\} \\
K_{z x(2)}^{1}=2 K_{x z(2)}^{1}=\gamma R\left[\frac{D}{R^{2}} \frac{-1+\nu_{(2)}}{2}\right. \\
\left.\quad+\frac{K}{R^{4}}\left\{\frac{-1+\nu_{(2)}}{2}+(\gamma R)^{2}\right\}\right] \\
\left.K_{z z(2)}^{1}=\frac{D}{R^{2}}\left\{\frac{1-\nu_{(2)}}{2}+(\gamma R)^{2}\right\}+\frac{K}{R^{4}} \frac{1-\nu_{(2)}}{2}\right\}
\end{array}\right\}
$$

地震に対する構造物の $x$ 方向と $z$ 方向の 1 次モード 応答振幅は, 右辺の $U_{x(1)}^{1, f}$ に対し, $U_{x(1)}^{f}=U_{s(1)}^{f} \cos \phi$ を代入することで求めることができる.

\section{（3）構造物に生じる軸ひずみの評価}

地震波に対する円筒構造物の縱断方向の応答変位は, 上述の計算によって求めた 0 次モードおよび 1 次モ一 ドの応答振幅から，次式で記述することができる。

$$
\left(\begin{array}{l}
u_{x(2)} \\
u_{z(2)}
\end{array}\right)=\left\{\left(\begin{array}{c}
0 \\
U_{z(2)}^{0}
\end{array}\right)+\left(\begin{array}{c}
U_{x(2)}^{1} \\
-i U_{z(2)}^{1} \cos \theta
\end{array}\right)\right\} e^{i(\gamma z-\omega t)}
$$

また，縦断方向の応答変位法による耐震設計で問題と すべき軸ひずみ $\varepsilon_{z z(2)}$ は次式で計算できる.

$$
\varepsilon_{z z(2)}=\frac{\partial u_{z(2)}}{\partial z}=i \gamma\left(U_{z(2)}^{0}-i U_{z(2)}^{1} \cos \theta\right) e^{i(\gamma z-\omega t)}
$$

なお, 式 (48), 式 (49) ともにそれぞれの振幅值は複素 数であり，位相情報を含んだものとなる.

図-11 や図-12 は構造物に生じる軸ひずみの最大振 幅 (振幅の絶対值) を計算し, 比較したものである.こ こでも，自然地盤でのせん断ひずみが 1 となる $\mathrm{S}$ 波が 入射する場合を考える. 凡例の $\varepsilon_{z z(e)}^{0}, \varepsilon_{z z(e)}^{1}$ は弾性波 動論から得られるもの, $\varepsilon_{z z(s)}^{0}, \varepsilon_{z z(s)}^{1}$ は本報で提案し た構造物を円筒シェルと仮定した応答変位法から得ら れるものとする．構造物に生じる軸ひずみの最大值は 0 次モードの方が 1 次よりも大きく, 0 次モードの軸ひ ずみは周波数が低いほど大きい，また，軸ひずみが最 大となる際の軸方向の見かけの波長 (入射角) は 0 次と 1 次で異なっている. 


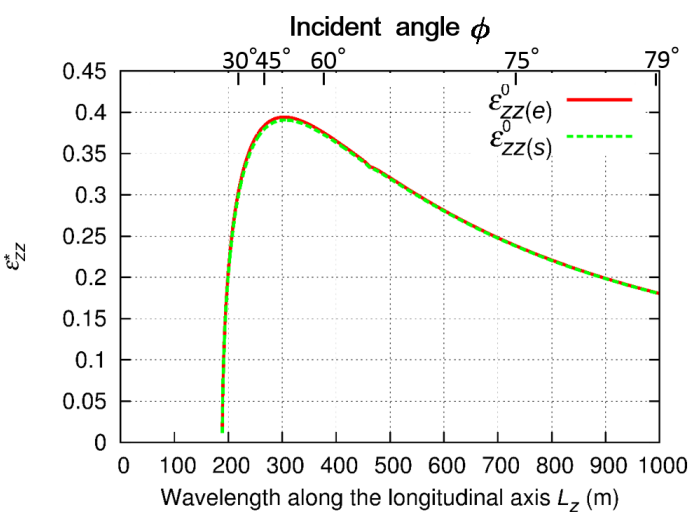

(a) 0 次モード

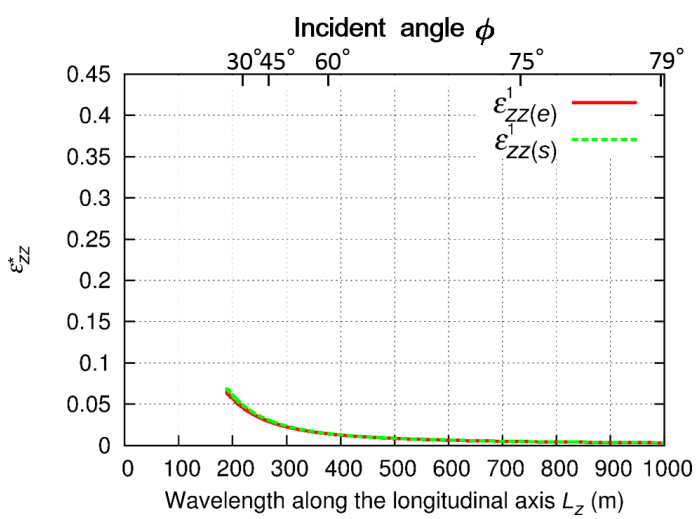

(b) 1 次モード

図-11 構造物に生じる軸ひずみの最大振幅の比較 (周波数 $1.00 \mathrm{~Hz})$

なお，ここでは周波数を変化させて考察しているが, 解は地震波の波長と構造物の大きさの比で決まるため, 例えば，半径 $R$, 厚さ $h$ の構造物に周波数 $5.00 \mathrm{~Hz}$ の S 波が入射した際の構造物内壁面に生じる最大軸ひずみ と, 半径 $5 R$, 厚さ $5 h$ の構造物に周波数 $1.00 \mathrm{~Hz}$ の $\mathrm{S}$ 波 が入射した際のそれは同じである.

図-13 は構造物内壁面に生じる軸ひずみの最大振幅を 比較したものである.凡例の $\varepsilon_{z z(e)}$ は弾性波動論で 0 か ら 10 次までの応答を位相を考慮した上で重ね合わせて 得られるほぼ厳密解を表す。 $\varepsilon_{z z(s)}$ は構造物を円筒シェ ルと仮定した応答変位法で 0 次モードと 1 次モードの 応答を位相差を考慮した上で重ね合わせたもの, $\varepsilon_{z z\left(s^{\prime}\right)}$ は 0 次モードと 1 次モードそれぞれの最大応答を単純 に足し合わせたもの (位相を考慮していないもの)であ る. また，凡例内の数值は軸ひずみを計算した角度 $\theta$ の 值である。ここでの周波数は 1 次モードによる寄与が 大きい $5.00 \mathrm{~Hz}$ とし，軸ひずみが最大となった $\theta=180^{\circ}$ の結果を示している. $\varepsilon_{z z(s)}$ と $\varepsilon_{z z\left(s^{\prime}\right)}$ の最大值の差異 は約 $20 \%$ である．構造物に生じる軸ひずみは位相を考 慮した方が合理的な值となるが，考慮しない場合でも， 大きく過大評価してしまうということはない.

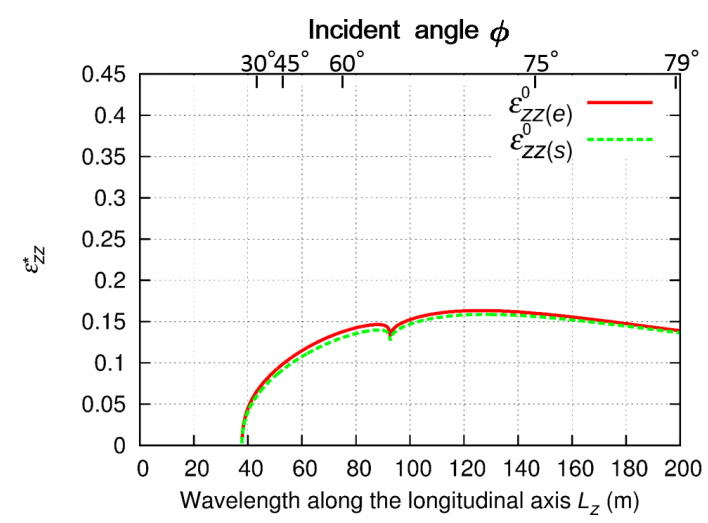

(a) 0 次モード

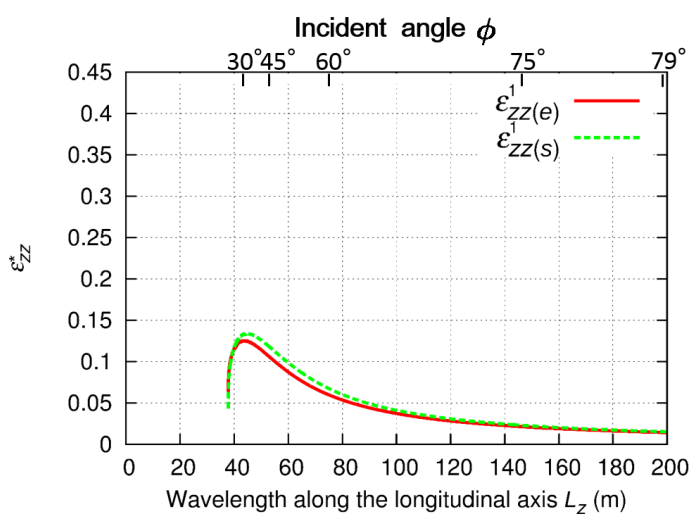

(b) 1 次モード

図-12 構造物に生じる軸ひずみの最大振幅の比較 (周波数 $5.00 \mathrm{~Hz}$

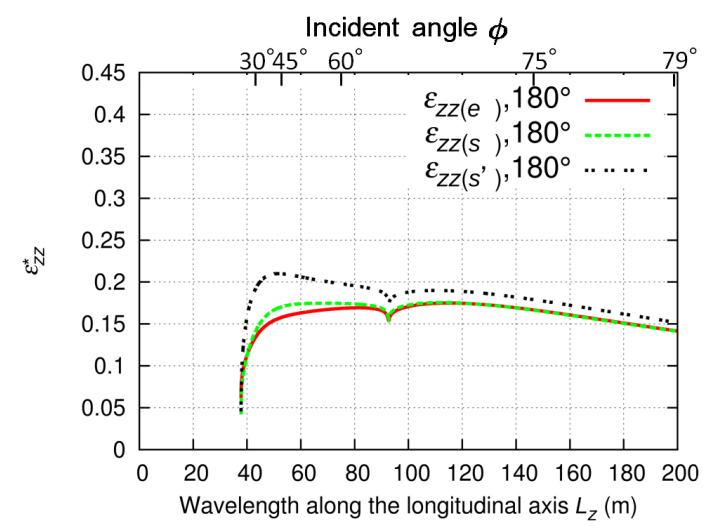

図-13 構造物内壁面に生じる軸ひずみの最大振幅の比較 (周 波数 $5.00 \mathrm{~Hz}$ )

\section{7. まとめ}

本論文では，地震時に線状地中構造物に生じる軸直 交方向の変形を応答変位法により評価することの妥当 性について，弾性波動論の立場から再考した。その結 果として，一般的な周波数の $\mathrm{S}$ 波の入射を想定した場 合，以下のことがいえる。 
- 構造物を梁でモデル化すると, 構造物の曲げ変形 に伴い生じる軸方向の変形が地盤に拘束される影 響，および軸方向の切り欠き力による影響を考慮 できない，その結果，軟質地盤内の円筒地中構造 物に対して S 波が浅い角度で入射するような場合 では, 構造物に生じる軸ひずみを過大評価する.

- 構造物を円筒シェル, 周辺地盤を各方向に独立な 軸方向と軸直交方向の 2 つの地盤ばねで表し，入 力に自然地盤変位と切り欠き力を用いた応答変位 法は, 円筒地中構造物の軸曲げ変形を上手く評価 でき，弾性波動論の厳密解とも良く一致する。

- 構造物に生じる軸ひずみの最大值は軸方向変位に よるものの方が軸直交方向変位によるものよりも 大きい，また，その最大值は位相を考慮した方が 合理的な值となるが，考慮しない場合でも，大き く過大評価してしまうということはない.

以上の議論はある理想状態を仮定した場合のもので あり, 実際には地盤条件や構造条件は複雑なものとな る. 複雑な条件下では, 地盤ばねを厳密に定めること はできないが, 本研究で提案したものはその参考值に なるものと考えられる. なお，図-5 に, トンネル軸方向のみかけの波長が短くなると, 地 盤ばねのような単純化したモデルは不適となる．その ため, 地盤に局所的な変形が生じる問題, 例えば, 伸縮 可能な構造継手や目地の目開きを考慮した問題を応答 変位法で扱う場合には，注意が必要である，構造物に 生じる軸ひずみは, 基本的には軸力 (軸伸縮変形) が卓 越すると考えられるので, 構造物を梁として評価して も大きな問題はない. ただし，曲げモーメント (軸曲げ 変形) による大きな軸ひずみが生じる場合は, 円筒シェ ルのような軸方向の力の釣り合いも考慮できるモデル で再評価することが望ましい.

\section{付録 I 円筒座標系で表された地盤の剛性}

弾性波動論の基礎方程式である式 (20) を満足する変 位の一般解は式 (21) で表すことができ, ポテンシャル 関数 $\varphi, \psi, \chi$ の一般解が式 (32) のようにおける場合, 円筒空洞壁面 $(r=R)$ における変位の一般解である式 (3) の係数 $U_{r}^{1}, U_{\theta}^{1}, U_{z}^{1}$ は次式となる. なお, 以降の $\varepsilon_{j k}^{(i)}$ の記号は文献 5) に倣っている。 また，下付き添字 (1) の記載は省略する。

$$
\left(\begin{array}{c}
U_{r}^{1} \\
U_{\theta}^{1} \\
U_{z}^{1}
\end{array}\right)=\frac{1}{R}\left(\begin{array}{ccc}
\varepsilon_{71}^{(3)} & \varepsilon_{72}^{(3)} & \varepsilon_{73}^{(3)} \\
\varepsilon_{81}^{(3)} & \varepsilon_{82}^{(3)} & \varepsilon_{83}^{(3)} \\
-i \varepsilon_{91}^{(3)} & -i \varepsilon_{92}^{(3)} & -i \varepsilon_{93}^{(3)}
\end{array}\right)\left(\begin{array}{c}
A_{1} \\
B_{1} \\
C_{1}
\end{array}\right)
$$

土木学会論文集A1 構造 地震工学), Vol. 74, No. 1, 44 57, 2018.

ここで， $\varepsilon_{71}^{(3)}, \varepsilon_{72}^{(3)}$ などはそれぞれ次式となる.

$$
\begin{aligned}
& \varepsilon_{71}^{(3)}=\alpha R H_{0}^{(1)}(\alpha R)-H_{1}^{(1)}(\alpha R) \\
& \varepsilon_{72}^{(3)}=H_{1}^{(1)}(\beta R) \\
& \varepsilon_{73}^{(3)}=\frac{i \gamma}{k_{s}}\left\{\beta r H_{0}^{(1)}(\beta R)-H_{1}^{(1)}(\beta R)\right\} \\
& \varepsilon_{81}^{(3)}=-H_{1}^{(1)}(\alpha R) \\
& \varepsilon_{82}^{(3)}=-\left\{\beta R H_{0}^{(1)}(\beta R)-H_{1}^{(1)}(\beta R)\right\} \\
& \varepsilon_{83}^{(3)}=-\frac{i \gamma}{k_{s}} H_{1}^{(1)}(\beta R) \\
& \varepsilon_{91}^{(3)}=i \gamma R H_{1}^{(1)}(\alpha R) \\
& \varepsilon_{92}^{(3)}=0 \\
& \varepsilon_{93}^{(3)}=\frac{\beta^{2} R}{k_{s}} H_{1}^{(1)}(\beta R)
\end{aligned}
$$

また, 円筒空洞壁面 $(r=R)$ における表面力の一般解 は式 (21) の変位の一般解, 変位-ひずみの関係式, 等 方均質体のひずみ一応力の関係式を用いて整理すること で導出でき, 表面力の一般解の式 (5) の係数 $F_{r}^{1}, F_{\theta}^{1}$, $F_{z}^{1}$ は次式となる.

$$
\left(\begin{array}{c}
F_{r}^{1} \\
F_{\theta}^{1} \\
F_{z}^{1}
\end{array}\right)=-\frac{2 \mu}{R^{2}}\left(\begin{array}{ccc}
\varepsilon_{11}^{(3)} & \varepsilon_{12}^{(3)} & \varepsilon_{13}^{(3)} \\
\varepsilon_{41}^{(3)} & \varepsilon_{42}^{(3)} & \varepsilon_{43}^{(3)} \\
-i \varepsilon_{51}^{(3)} & -i \varepsilon_{52}^{(3)} & -i \varepsilon_{53}^{(3)}
\end{array}\right)\left(\begin{array}{l}
A_{1} \\
B_{1} \\
C_{1}
\end{array}\right)
$$

ここで, $\varepsilon_{11}^{(3)}, \varepsilon_{12}^{(3)}$ などはそれぞれ次式となる.

$\varepsilon_{11}^{(3)}=\left(2-\frac{k_{s}^{2}+2 \gamma^{2}}{2} R^{2}\right) H_{1}^{(1)}(\alpha R)-\alpha R H_{0}^{(1)}(\alpha R)$

$\varepsilon_{12}^{(3)}=-2 H_{1}^{(1)}(\beta R)+\beta R H_{0}^{(1)}(\beta R)$

$\varepsilon_{13}^{(3)}=\frac{i \gamma}{k_{s}}\left\{\left(2-\beta^{2} R^{2}\right) H_{1}^{(1)}(\beta R)-\beta R H_{0}^{(1)}(\beta R)\right\}$

$\varepsilon_{41}^{(3)}=2 H_{1}^{(1)}(\alpha R)-\alpha R H_{0}^{(1)}(\alpha R)$

$\varepsilon_{42}^{(3)}=\left(-2+\frac{\beta^{2} r^{2}}{2}\right) H_{1}^{(1)}(\beta R)+\beta r H_{0}^{(1)}(\beta R)$

$\varepsilon_{43}^{(3)}=\frac{i \gamma}{k_{s}}\left\{2 H_{1}^{(1)}(\beta R)-\beta r H_{0}^{(1)}(\beta R)\right\}$

$\varepsilon_{51}^{(3)}=i \gamma R\left\{-H_{1}^{(1)}(\alpha R)+\alpha r H_{0}^{(1)}(\alpha R)\right\}$

$\varepsilon_{52}^{(3)}=\frac{i \gamma R}{2} H_{1}^{(1)}(\beta R)$

$\varepsilon_{53}^{(3)}=\frac{\left(\beta^{2}-\gamma^{2}\right) R}{2 k_{s}}\left\{-H_{1}^{(1)}(\beta R)+\beta r H_{0}^{(1)}(\beta R)\right\}$

なお, 式 (I.3) の符号のマイナスは応力と表面力の符号 の定義の違いによるものである.

式 (6), 式 (I.1), 式 (I.3)より円筒座標系で表された 
地盤の剛性は次式で計算できる。

$$
\begin{aligned}
& \left(\begin{array}{lll}
K_{r r}^{1} & K_{r \theta}^{1} & K_{r z}^{1} \\
K_{r \theta}^{1} & K_{\theta \theta}^{1} & K_{\theta z}^{1} \\
K_{r z}^{1} & K_{\theta z}^{1} & K_{z z}^{1}
\end{array}\right)= \\
& -\frac{2 \mu}{R}\left(\begin{array}{ccc}
\varepsilon_{11}^{(3)} & \varepsilon_{12}^{(3)} & \varepsilon_{13}^{(3)} \\
\varepsilon_{41}^{(3)} & \varepsilon_{42}^{(3)} & \varepsilon_{43}^{(3)} \\
-i \varepsilon_{51}^{(3)} & -i \varepsilon_{52}^{(3)} & -i \varepsilon_{53}^{(3)}
\end{array}\right)\left(\begin{array}{ccc}
\varepsilon_{71}^{(3)} & \varepsilon_{72}^{(3)} & \varepsilon_{73}^{(3)} \\
\varepsilon_{81}^{(3)} & \varepsilon_{82}^{(3)} & \varepsilon_{83}^{(3)} \\
-i \varepsilon_{91}^{(3)} & -i \varepsilon_{92}^{(3)} & -i \varepsilon_{93}^{(3)}
\end{array}\right)^{-1}
\end{aligned}
$$

\section{参考文献}

1) 川島一彦: 地下構造物の耐震設計, 鹿島出版会, 1994.

2) 土木学会: シールドトンネルの耐震検討, 2007.

3) 日本水道協会: 水道施設耐震工法指針・解説, 1986 .
4) 保田尚俊, 塚田和彦, 朝倉俊弘 : 円筒地中構造物に生じる 軸方向の変形の応答変位法を用いた評価に関する理論的 考察, 土木学会論文集 A1, Vol. 70, No. 2, pp. 306-318, 2014.

5) Mow, C. and Pao, Y.: The Diffraction of Elastic Waves and Dynamic Stress Concentrations, Rand Corporation, 1971.

6) 保田尚俊, 塚田和彦, 朝倉俊弘 : 3 次元弾性波動論に基づ いた山岳トンネルの地震被害メカニズムに関する考察, 土 木学会論文集 F1, Vol. 70, pp. 1-14, 2014.

7）立石章 : 応答変位法における地震荷重の作用方法に関する 研究, 土木学会論文集, No. 441/I-18, pp. 157-166, 1992.

8) Flügge, W.: Stress in Shells, Berlin and New York: Springer-Verlag, 1973.

\title{
RECONSIDERATION OF SEISMIC DEFORMATION METHOD FOR LONGITUDINAL BENDING DEFORMATION OF CYLINDRICAL UNDERGROUND STRUCTURE
}

\author{
Naotoshi YASUDA, Kazuhiko TSUKADA and Toshihiro ASAKURA
}

\begin{abstract}
The seismic deformation method to evaluate the longitudinal bending deformation of cylindrical underground structure is reconsidered through the exact solution based on the eigenfunction expansion method. The results show that the seismic deformation method can evaluate the longitudinal bending deformation of cylindrical underground structure when the structure is treated as an elastic shell, with the surrounding ground treated as elastic foundation springs in axial and axis orthogonal directions and the input ground displacement treated appropriately. On the other hand, conventional seismic deformation method that assumes the structure as a beam overestimates the maximum axial strain of the lining because beam theory ignore the equilibrium of force in the axial direction.
\end{abstract}

